\title{
ALLOCATING RESOURCES AMONG PRISONS AND SOCIAL PROGRAMS IN THE BATTLE AGAINST CRIME
}

\author{
JOHN J. DONOHUE III and PETER SIEGELMAN*
}

\begin{abstract}
This article evaluates the cost and crime-reducing potential of prisons and social spending, setting forth the conditions under which a shift in resources from an expanding prison population into social spending would lead to a reduction in total crime. Preschool enrichment programs coupled with family intervention have generated impressive results in reducing crime in a number of different studies. Targeting of resources toward those children most at risk of criminal behavior is necessary to generate cost-effective crime reduction, but this may be difficult to achieve because of political or constitutional constraints. Given precise targeting, and if a broadly implemented preschool program (more enriched than the current Head Start program) could generate half the crime-reduction benefits achieved in the pilot studies, then cutting spending on prisons and using the savings to fund intensive preschool education would reduce crime. The elasticity of crime with respect to incarceration is taken to be .15 .
\end{abstract}

\section{INTRODUCTION}

$\mathrm{T}$ HIS article provides a large-scale overview of governmental crimefighting expenditures and asks whether society is allocating these resources

* Donohue is a professor at Stanford Law School and a Research Fellow at the National Bureau of Economic Research. Siegelman is an instructor at Yale Law School. We are grateful for helpful comments from Ian Ayres, Ramamoorthi Bhaskar, Boris Bittker, Philip Cook, Shari Diamond, James Heckman, Dan Klerman, Steve Levitt, Saul Levmore, Mitch Polinsky, Dan Polsby, Paul Robinson, Rob Sampson, Steven Schulhofer, Susan Shapiro, Cass Sunstein, and Joel Waldfogel and from workshop participants at Stanford Law School; Indiana University School of Law, Indianapolis; DePaul Law School; Northwestern University School of Law; the University of Chicago Law School; Yale Law School; the American Bar Foundation; and the 1994 May meeting of the American Law and Economics Association in Stanford, Ca. Lillie Ibayan, Jason Freitag, and especially Dawn Jeglum-Bartusch deserve thanks for their research assistance. Rozanne Caldwell produced many drafts of this manuscript with good humor and great skill. We are pleased to acknowledge the generous research support of the American Bar Foundation. Part of this work was completed while Siegelman was an Olin Visiting Fellow in Law and Economics at Yale Law School. A substantially longer and more detailed version of this article is available from us on request. Donohue: JJD@Leland. Stanford.Edu. Siegelman: Siegelman@Mail.Law.Yale.Edu. 
in an optimal way across two important crime-reducing "technologies": prisons and social programs. Unless the government spends in such a way that the marginal benefit (the crime reduction achieved from the last dollar spent) is the same for each activity, society will not be fighting crime in a cost-effective manner. In such cases, reallocating resources toward higherpayoff approaches will lower crime for any given level of expenditure. ${ }^{1}$

The goal of this article, then, is to provide a rough empirical assessment of whether our current policy of increasing reliance on incarceration and declining use of social spending is the best way to spend our crime-reduction dollars. To do this, we begin in Section II by assessing incarceration as a crime control strategy, demonstrating that the effects on crime of further increases in the number of prisoners are likely to be modest, especially given the substantial run-up in the prison population over the past 3 decades. Section III looks at several different kinds of social programs that are alleged to reduce criminal behavior. While the evidence is far from perfect, we do find several programs that appear to generate substantial reductions in crime at reasonable cost. Finally, Section IV explicitly considers the implications of shifting expenditures away from the massive increases being channeled into prison construction and incarceration to some of the successful social programs. We describe the conditions under which it would be possible to reduce spending on prisons, use the money to fund social programs, and reduce the overall crime rate in the process.

It may be helpful to provide a summary of our major conclusions. If the implicit assumption of every study of which we are aware is correct that the elasticity of crime with respect to incarceration is constant, then each subsequent increase in the prison population will cost increasingly more to generate the same percentage reduction in crime. In our earlier work, we demonstrated that given an elasticity of crime in the neighborhood of 10 20 percent, past increases in incarceration were cost beneficial, but future increases were increasingly more problematic. For example, a doubling of the current prison population - which would entail an additional social cost of roughly $\$ 36$ billion per year-would likely decrease crime by only about $10-20$ percent. While many social programs have been ineffective, there is evidence that early childhood intervention-of a more costly and more valuable kind than is currently offered by Head Start-can reduce future crim-

\footnotetext{
${ }^{1}$ A longer version of this article (John J. Donohue III and Peter Siegelman, Is the United States at the Optimal Rate of Crime? Allocating Resources among Prisons, Police, and Social Programs (unpublished manuscript, Stanford University and the American Bar Foundation, 1996)) contains an extended discussion of the costs of crime; with estimates of these costs, we are able to say something about whether the total spending on crime-control is roughly optimal. Here, we ignore the question of the total volume of spending and focus only on the allocation of crime-fighting expenditures between prisons and social programs.
} 
inality. The crucial question is whether we could replicate the most successful preschool interventions on a large scale without reducing their effectiveness by more than 50 percent. If so, and if we can target such preschool spending on the most crime-prone individuals (low-income, innercity males), and if the reductions in criminal conduct of program participants are not offset by increased criminal behavior by nonparticipants, we argue that diverting resources from continuing large increases in incarceration and directing the social savings to preschool interventions could reduce crime without increasing spending.

It is likely that a full assessment of both the other benefits that flow from social programs and the social costs of enforcing criminal law through a punitive system would strengthen the case for stopping further prison expansion. The factual predicates of the value of enriched preschool programs should quickly be explored through expanded experimental programs whose results are carefully analyzed. Finally, a more precise estimate of the elasticity of crime with respect to incarceration would be a significant aid in wise policy making since high-end estimates suggest a greater scope for further prison population increases and more moderate or low-end estimates suggest that further prison growth should be curtailed with the saved resources channeled to social programs.

\section{INCARCERATION}

Over the last 2 decades, the United States has tipped strongly toward incarceration as the major crime-fighting strategy, resulting in a prison population that is both unprecedentedly large and rapidly growing. As of December 1993, the United States was incarcerating about 925,000 individuals in state and federal prisons, a rate of over 300 per 100,000 Americans. Today, the prison population is well over 1 million. This level of incarceration is unprecedented in this country's history and throughout the world today. Moreover, these figures do not include the more than 500,000 who are currently in jail or in juvenile detention facilities.

As Figure 1 reveals, the rate of incarceration in the United States varied within a narrow band of roughly $100-120$ prisoners per 100,000 total population between 1933 and 1973. Since 1974, however, the incarceration rate has risen dramatically, with no evidence of any slowdown. The current rate of growth requires the equivalent of almost two new 1,000-inmate prisons to open every week.

\section{A. The Costs of Incarceration}

A number of studies have tried to estimate the cost of keeping a convicted criminal in prison for a year. They have typically evaluated the an- 


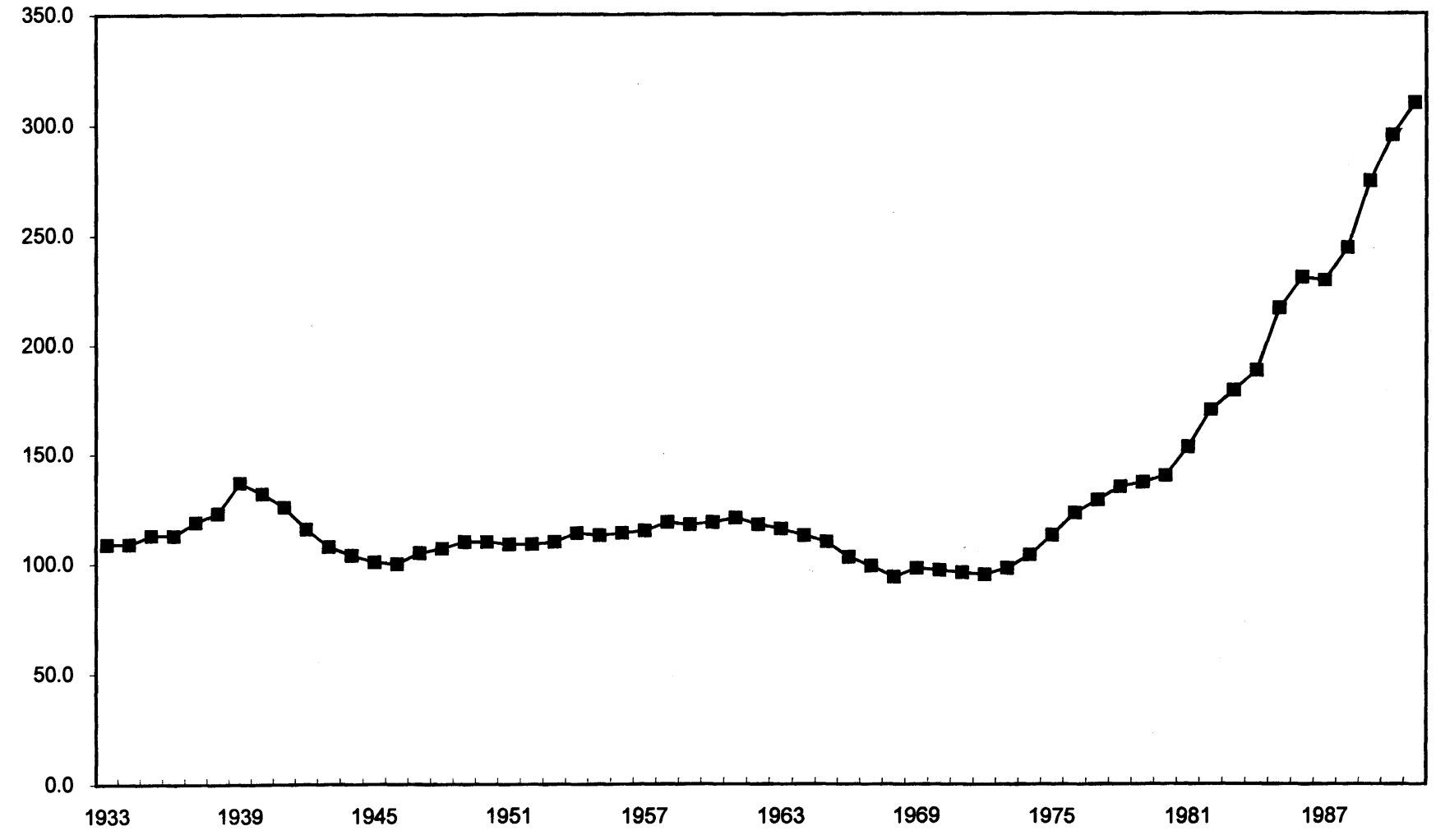

FIGURE 1.-The incarceration rate in the United States: the rate per 100,000 inhabitants 
nual custodial costs of housing, clothing, and supervising an inmate, the amortized cost of constructing the prison cell, and the attendant social costs of incarceration, such as the lost legitimate production and the increased welfare dependency of the families of inmates. Based on this approach, these studies have estimated the annual cost of locking up an inmate (in 1993 dollars) to be $\$ 25,000,,^{2} \$ 32,000,{ }^{3}$ and $\$ 45,000 .^{4}$ The latter figure, which comes from the BOTEC report, ${ }^{5}$ is the most carefully constructed and comprehensive; we adjust it in two ways to generate our own estimate.

First, 20 percent of the BOTEC report's cost of incarceration comes from the estimated increase in "welfare costs to [support] inmate's dependents," which we omit since the increased welfare payments are not a social cost but a transfer from taxpayers to welfare recipients. ${ }^{6}$ Second, we believe that the BOTEC report exaggerates the amortized construction cost of a prison cell. ${ }^{7}$ Our resulting estimate of the annual cost of incarcerating an additional inmate is about $\$ 36,000$ (in 1993 dollars), which includes the cost of building and occupying a prison cell, plus the lost legitimate wages of the occupant.

Other factors are also relevant to assessing the cost of incarceration. Im-

2 John J. DiIulio, Jr., and Anne M. Piehl, Does Prison Pay? 9 Brookings Rev 28 (1991); Anne M. Piehl and John J. Dilulio, Jr., "Does Prison Pay?"' Revisited, 13 Brookings Rev 20 (1995).

${ }^{3}$ Edwin Zedlewski, Making Confinement Decisions, Natl Inst Just, Res Brief 2 (July 1987).

${ }^{4}$ David Cavanagh and Mark Kleiman, A Cost-Benefit Analysis of Prison Cell Construction and Alternative Sanctions (report prepared for the National Institute of Justice under contract OJP-90-M-141, June 20, 1990) (hereafter, the BOTEC report).

${ }^{5}$ Id at 13.

${ }^{6}$ Note that raising revenues through distortionary taxes to pay the welfare expenses will involve a social cost, but this cost is measured by the deadweight loss imposed by the taxes, rather than the size of the welfare payments themselves. This same deadweight loss exists whenever taxes are used to pay for any public expenditures-including those on prisons, police, and public education.

Even if one wanted to include the higher welfare expenditures as a cost of incarceration, the BOTEC report overestimates this expense. Cavanagh and Kleiman estimate that the combined annual cost of Aid to Families with Dependent Children (AFDC), Food Stamp, and Medicaid payments equals $\$ 19,554$ (in 1989 dollars). Id at 16 . Noting that 43 percent of the prison inmates have dependents, they estimate the per-inmate welfare cost to be 43 percent of the $\$ 19,554$. But surely many of these dependents would be on welfare even if the prisoner were not incarcerated, and it is only the marginal cost that would be relevant. We should note that BOTEC report was in all likelihood being generous in its assessment of the cost of prisons, which would have been a conservative approach given its conclusion that the benefits of incarceration far exceeded the costs.

7 The BOTEC report uses a nominal interest rate in computing the annualized cost at $\$ 4,094$ (in 1989 dollars) per cell. We simply take their estimated construction cost and compute the equivalent annual cost using a 4.5 percent real discount rate, which equals $\$ 2,982$ (in 1993 dollars). 
prisonment may impose costs on the inmate's family-the loss of the company of a parent or spouse and any attendant costs to those families involuntarily thrust on welfare. Indeed, one might even argue that the disutility to the prisoner himself is a social cost, although for some crimes, the public may feel positive benefits from this disutility.

Incarceration imposes social costs if time in prison impairs the productivity of prisoners after their release ${ }^{8}$ or prevents the accumulation of legitimate job experience. ${ }^{9}$

While we think it likely that these social costs exceed the social benefits we have omitted-the public's benefit from seeing an individual punished plus the value of prison inmate production-we do not augment our estimated cost of incarceration because their appropriate magnitude is uncertain, and we choose to be conservative in making our calculations. In the next section, we turn to the question of how much crime reduction we could secure by spending $\$ 36,000$ per year to incarcerate another criminal.

\section{B. How Much Crime Does Incarceration Prevent?}

Many policy analysts have trumpeted the benefits of incarceration as a crime-control strategy. The titles of recent articles- "Doubling the Prison Population Will Break America's Crime Wave," 10 and "Prisons Are a Bargain, by Any Measure" -reflect this common viewpoint. ${ }^{11}$ These sentiments have garnered the support of many citizens and politicians, as evi-

${ }^{8}$ Robert Sampson and John Laub have found that juveniles who are sentenced to prison do less well than otherwise-similar juveniles who are not. They conclude that "imprisonment may have powerful negative effects on the prospects of future employment and job stability." Robert Sampson and John Laub, Crime in the Making: Pathways and Turning Points through Life 255 (1993).

There is a growing empirical literature in economics about the effect of conviction on future earnings. See Daniel Nagin and Joel Waldfogel, The Effects of Criminality and Conviction on the Labor Market Status of Young British Offenders, 15 Internatl Rev L \& Econ 109 (1995); Daniel Nagin and Joel Waldfogel, The Effect of Conviction on Income through the Life Cycle (Working Paper No 4551, National Bureau of Economic Research 1993); Jeffrey Grogger, Arrests, Persistent Youth Joblessness, and Black/White Employment Differentials, 74 Rev Econ \& Statistics 100 (1992); Ann Witte and Pamela Reid, An Exploration of the Determinants of Labor Market Performance of Prison Releasees, $56 \mathrm{~J}$ Urban Econ 313 (August 1980).

${ }^{9}$ As we discuss in the longer version of this article (cited in note 1), the present discounted value of the cost of a year of lost experience could be as high as $\$ 10,000$ (in 1993 dollars) if prisoners would have worked continuously in legitimate jobs had they not been incarcerated and would they work continuously on release. Of course, such continuous legitimate work experience would be unusual for many inmates.

${ }^{10}$ Eugene Methvin, Doubling the Prison Population Will Break America's Crime Wave, Corrections Today 28 (February 1992).

1 John Dilulio, Prisons Are a Bargain, by Any Measure, NY Times A19 (January 16, 1996). 
denced by the rapidly growing prison population and the nationwide effort to enact "Three Strikes and You're Out" laws.

Two approaches have been used to estimate the crime-reducing effects of incarceration. The first focuses exclusively on the amount of crime that is avoided through the incapacitative effects of incarceration. The idea underlying this line of research is simply that by removing a convicted criminal from society and placing him in prison, we can eliminate the crimes he would have otherwise committed. Although the insight seems commonsensical, empirical estimation turns out to be trickier than one might imagine and requires some sophisticated statistical modeling. ${ }^{12}$ The second approach tries to estimate the total crime reduction associated with increased incarceration without distinguishing between incapacitation and deterrence effects. Using aggregate (usually state-level) data, these studies in essence test the proposition that higher imprisonment rates are associated with lower rates of crime, while controlling for other factors. We discuss each of these two approaches in turn.

\section{Pure Incapacitation Effects}

Incapacitation as a solution to the crime problem has a certain intuitive appeal. One thing we clearly know how to do is build prisons and house people in them. If nothing else, criminals who are in prison cannot commit any crimes against the rest of society. Unlike social programs, the "technology" of incarceration is well proven, begins to work immediately in reducing crime, and requires little except money to accomplish its primary goal-keeping convicted criminals off the streets. But while incarceration may be a low-risk strategy of fighting crime, it is not inexpensive: one needs to prevent a lot of crime to justify the roughly $\$ 36$ million it costs to lock up an extra 1,000 prisoners. Unfortunately, close examination suggests that the incapacitative effect of prison is much less powerful than one might at first imagine.

We begin exploring the effects of incapacitation by looking at only one

${ }_{12}$ The pioneers in the statistical modeling of incarceration-using techniques derived from the queuing theory literature in operations research-were B. Avi-Itzhak and R. Shinnar, Quantitative Models in Crime Control, 1 J Crim Just 185 (1973); and R. Shinnar and S. Shinnar, The Effect of the Criminal Justice System on the Control of Crime: A Quantitative Approach, 9 L \& Socy Rev 581 (1975). We focus on the more recent efforts of Jacqueline Cohen and Jose A. Canela-Cacho, Incarceration and Violent Crime: 1965-1988, in Albert J. Reiss, Jr., and Jeffrey A. Roth, eds, Understanding and Preventing Violence, Vol 4: Consequences and Control (1994); and especially William Spelman, Criminal Incapacitation (1994).

Zedlewski (cited in note 3 ) and the BOTEC report (cited in note 4) estimate incarceration effects using a framework that drastically overstates the benefits of incapacitative effects of prisons, as we argue below. 
TABLE 1

Estimates of the Proportion of All Robberies

Prevented by the Current Prison Population, DUE to InCAPACITATION Alone

\begin{tabular}{lc}
\hline \hline Study & $\begin{array}{c}\text { Incapacitation Effect } \\
\text { (in Percent)* }\end{array}$ \\
\hline Avi-Itzhak and Shinnar $\dagger$ & $4.7-7.8$ \\
BOTEC (low) $\ddagger$ & 11 \\
Spelman $§$ & 21 \\
Cohen and Canela-Cacho & $28-41$ \\
Zedlewski $\ddagger$ & 107 \\
BOTEC (high) $\ddagger$ & 174 \\
\hline
\end{tabular}

NoTE.-Sources can be found in indicated article notes.

* This is the percentage increase in the number of robberies if (a) the current population of prisoners were set free, without replacing them, and $(b)$ there were no behavioral response by anyone to the new (zero) risk of incarceration. See text for further details.

$\dagger$ Cited in note 12. The range covers estimates for Texas, California, and Michigan. Calculated by Cohen and Canela-Cacho, p. 331 (cited in note 12).

$\ddagger$ The BOTEC (cited in note 4) and Zedlewski (cited in note 3) estimates were derived by taking

$$
\frac{\text { (no. of persons in prison) } \cdot \hat{c}}{\text { (no. of robberies) }} \text {, }
$$

where $c$ is the author's estimate of the number of robberies prevented by imprisoning one robber for 1 year. We use 104,700 as the number of imprisoned robbers in 1991 (U.S. Department of Justice, Bureau of Justice Statistics, Sourcebook, 1993, table 6.41) and $1,203,000$ as the number of robberies (table 3.2). The number of robberies is measured from the National Crime Victimization Survey.

$\S$ Cited in note 12 , p. 217 . Spelman calculates that there is a 90 percent probability that the true value is between 15 and 28 percent. The estimate is for all crimes, not robbery taken separately.

|l Cited in note 12, pp. 330-31.

crime-robbery. Table 1 presents a range of estimates for the "pure" incapacitative effect of prison on the number of robberies. Conceptually, it measures the increase in the number of robberies that would result if the current population of prisoners were set free..$^{13}$ The table gives a sense of the extremely large range of estimates for the incapacitative effects of the prison system: the lowest estimate is that current incapacitation alone prevents only a 5 percent increase in robberies, while the highest estimate suggests

${ }^{13}$ This calculation is made assuming that the freed prisoners are not replaced by any new arrestees and that actual or potential criminals would not alter their behavior in response to the lower (zero) risk of incarceration. Both of these counterfactuals are, of course, wildly implausible, but they are useful in comparing the various (upper-bound) estimates of the effects of incarceration on crime. 
that robberies would rise by almost 175 percent if the current prisoner population were freed.

These estimates are all derived from a roughly similar family of statistical models, although with widely varying degrees of complexity and sophistication. ${ }^{14}$ The most important variables in these models are

- the distribution of $\lambda$, the number of crimes committed per criminal per year-both for criminals in the overall population and among those in prison;

- the distribution of career length (number of years over which a criminal is active, when not in prison); and

-the probability of arrest (and conviction), which may vary with $\lambda$.

This family of models suffers from four potentially important problems that can exaggerate the estimated effectiveness of incapacitation.

1. Distortions in Self-Reports of Crime. One drawback faced by all these models is that they require data that can only be obtained by asking prisoners how many crimes they have committed. Yet the prisoners may well either exaggerate or understate the extent of their criminal behavior, which cannot be ascertained since there are no independent sources against which their reports can be checked. Self-reports of arrests, however, can be checked against official records: such checks generally reveal that "[t]he self-reports of most offenders squared with their official records, with few or no disparities." ${ }^{15}$ But for those offenders who do not report accurately, the disparities between actual and self-reported arrests are not random. Instead, "offenders with few arrests systematically underestimate the number of times they are arrested ... [ [while those] with many arrests systematically overestimate." 16

William Spelman devotes considerable attention to the problems caused by biases in self-report data and proposes several solutions. Without such corrections, he notes, the use of raw self-report data makes incapacitation look more effective than it actually is. ${ }^{17}$ Several of the other studies do not correct for reporting biases or make only crude attempts to do so.

${ }_{14}$ The Zedlewski and BOTEC estimates are based largely on simple extrapolation, while Spelman (cited in note 12) and Cohen and Canela-Cacho (cited in note 12), are substantially more rigorous and nuanced.

${ }_{15}$ Spelman, at 47-48 (cited in note 12 ).

${ }^{16}$ Id at 53.

17 The net effect of the biases is to increase the mean, variance, and skewness of the offense rate $(\lambda)$ distribution. This in turn means that the average prisoner will appear to be committing more crimes (if free) than he actually would; it also means that the most crimeprone prisoners appear to be responsible for a greater share of all crime than they actually are. 
In addition to the problems with self-reports, many of the incapacitation models - such as those of Edwin Zedlewski and the BOTEC report-also fail to address a number of important issues. These include:

2. Distinguishing between Stocks and Flows. One method of calculating the effect of incarceration is to ask what would happen if we took the group of prisoners who were scheduled to be released and, instead of letting them out of prison, built enough new cells to keep them incarcerated for another year. A common error among researchers who employ this approach is to assume (implicitly) that those released from prison in any year are a random sample of all prisoners, when they in fact tend to be the less serious criminals. ${ }^{18}$ The problem stems from the failure to distinguish between the average number of crimes committed by the total stock of prisoners and the mean criminality of the group of prisoners who are poised to leave prison (the annual flow of releasees). When the prison population has been growing rapidly, however, there is likely to be a large difference between the composition of the stock and the flow. In particular, criminals with shorter-than-average sentences will be overrepresented among those who leave prison in any given year. If there is a positive correlation between sentence length and prior record, as seems likely, then the cohort of released prisoners will tend to have lower than average $\lambda s$ as well. Thus, the crimes prevented by keeping the current group of released prisoners incarcerated for an additional year will tend to be less than the average number of crimes committed by all prisoners-and probably dramatically so.

3. Distinguishing between Marginal and Average Criminality. It is well known that those in prison tend to have substantially higher $\lambda$ s than the "active criminal population" as a whole. ${ }^{19}$ The main reason for this divergence is that criminals who commit more crimes per year put themselves

${ }^{18}$ For example, the BOTEC report argues that, "[i]f one thousand additional cells are built, and are used to extend the prison terms of one thousand current inmates by 1 year, and if these prisoners are selected at random from the current prison population, then by the law of large numbers (the Central Limit Theorem of statistics) those inmates' annual rate of committing crimes before entering prisons will be the same as the average annual rate of all current prisoners. The net incapacitation effect will be as if each one of the thousand cells held a prisoner with the average annual crime commission rate of current prisoners." Id at 21 , emphasis in original. But note that such an extension of sentences will mean those sentenced to get out in 50 years will experience added incapacitation in a half-century, while those who were scheduled for release after a short sentence will be incapacitated further today. The latter group tends to have far lower crime commission rates.

${ }_{19}$ By failing to account for this problem, Avi-Itzhak and Shinnar (cited in note 12) understate the amount of crime prevented by incarceration. (See Table 1.) Cohen and CanelaCacho, at 331 (cited in note 12). 
at a higher annual risk of arrest. ${ }^{20}$ The consequence of this "self-selection" that puts the most-frequent criminals behind bars is that, other things being equal, expanding the prison population will increasingly bring in criminals with progressively lower $\lambda \mathrm{s}^{21}$ If, instead of keeping the current cohort of releasees in prison for an additional year, we bring in enough new prisoners to both replace the outflow and add to the total number behind bars, the new group is likely to be substantially less crime-prone than the average among all prisoners. Accordingly, estimates of the incapacitation effect, such as those of Zedlewski and the BOTEC report that are based on keeping the current prison population imprisoned for a longer period, overstate the benefits from simply locking up more criminals.

4. Replacement Effects. Zedlewski and the BOTEC report both assume that incarcerating a prisoner for an additional year will reduce crime by the number of crimes that the prisoner committed in the year prior to his incarceration. This may be plausible for some crimes but is certainly not true for others. For example, locking up a husband who batters his wife will probably reduce the beatings she will receive in the next year by the number he would inflict if he were free.

But much crime is not of this character. If, to use Zedlewski's figure, the average prisoner stole 51 cars in the year immediately prior to his incarceration, then his incapacitation is unlikely to reduce the number of auto thefts by 51 . Many crimes are committed by criminal rings or gangs; under these circumstances, the loss of one gang member will probably just lead to the recruitment of another. If the replacement thief is less talented or energetic than his predecessor, crime may fall-but one cannot simply assume that the decrease will be equal to the full 51 thefts. ${ }^{22}$ Better estimates of the incapacitative effect of imprisonment, such as Spelman's, use crime-specific adjustments for the replacement effect.

5. Career Lengths. It is widely recognized that most criminals do not

${ }^{20}$ There is one caveat: if the probability of arrest is strongly negatively related to $\lambda$ perhaps because more experienced criminals learn to outwit the police-then the worst (highest $\lambda$ ) criminals might not actually wind up in prison. Both Spelman and Cohen and CanelaCacho explicitly reject this possibility on both empirical and theoretical grounds.

${ }_{21}$ This point was made tellingly by Franklin Zimring and Gordon Hawkins in their critique of Zedlewski: The New Mathematics of Imprisonment, 34 Crime \& Delinquency 425, 43132 (1988). More mathematical discussions can also be found in Spelman and Cohen and Canela-Cacho.

${ }^{22}$ The BOTEC report acknowledges that using average crime rates may inflate incapacitation benefits, and Cavanagh and Kleiman adjust for "co-offending and replacement effects by [reducing the average crimes per inmate] figures by 0.3 ." Cavanagh and Kleiman, at 22 (cited in note 4). But even after applying this 30 percent downward adjustment, this report's "high" estimates for the effects of incapacitation are in most cases unrealistically large. 
commit offenses uniformly over their entire adult lifetimes. Instead, criminal behavior is disproportionately concentrated over a much shorter period, typically in the late teens and early twenties. ${ }^{23}$ This fact has obvious implications for the efficacy of imprisonment as a means of controlling crime. Consider a 20 -year-old who committed 40 crimes in the year prior to receiving a 10-year sentence. Simply multiplying 40 crimes/year by 10 years suggests that imprisoning this person would forestall 400 crimes over the next 10 years. But if the prisoner's criminal career would in any case have ended at age 25 , the true crime reduction is only 200 , and 5 years of the 10 -year sentence produce no incapacitative benefit. ${ }^{24}$

Only the study by Spelman attempts to fully correct for all of these factors, and thus, of all the studies of the incapacitative benefits of incarceration, we place the most confidence in his findings. Spelman's overall conclusion is that " $[\mathrm{w}] \mathrm{e}$ can be 90 percent confident that the true value [of the elasticity of crime with respect to incarceration] is between .12 and .20 , with a best, single guess of .16.",25

\section{Direct Estimates of the Benefits of Incarceration}

The direct estimates of the benefits of incarceration attempt to determine the total effect of increased incarceration on crime-whether the benefit comes from deterrence, incapacitation, or rehabilitation or is partially or fully reversed by whatever impetus to crime that imprisonment might provide.

For example, a recently published study by Thomas Marvell and Carlisle Moody has tried to directly estimate the elasticity of crime with respect to incarceration by examining crime statistics and prison populations for 49 states over the period 1971-89. ${ }^{26}$ The paper addresses the problems of simultaneity and identification in its econometric specification, while relying on the flawed FBI data for reported index crimes. ${ }^{27}$ Nonetheless, its conclu-

${ }^{23}$ See, for example, A. Blumstein, J. Cohen, J. Roth, and C. Visher, eds, Criminal Careers and "Career Criminals"' (1986).

${ }^{24}$ The prospect of a long sentence presumably would have some deterrent effect, but it is unclear whether sentencing one criminal to 10 years in jail or two criminals to 5 years each will lead to greater deterrence. If criminals were highly risk-averse, then the former might dominate, while if they have high discount rates or are risk preferrers, then the latter would deter more effectively.

${ }^{25}$ Spelman, at 220 (cited in note 12).

${ }^{26}$ Thomas Marvell and Carlisle Moody, Prison Population Growth and Crime Reduction, 10 J Quantitative Criminol 109 (1994).

${ }^{27}$ The companion to this article (Donohue and Siegelman; cited in note 1) explores the problems with the FBI (Uniform Crime Report) data in detail. Briefly, the major failing of the FBI data is that, owing to the effect of better computerization and recording, it tends to show increases in crime even when the crime rate is actually falling. If this pattern is uniform across all states, then the regression estimates of the impact of an increase in the prison popu- 
sion is virtually identical to that of Spelman. According to Marvel and Moody, "a one percent increase in prison population results in approximately 0.16 percent fewer reported index crimes," an elasticity of $0.16{ }^{28}$

Given that Spelman's elasticity estimate of 0.16 was based solely on the pure incapacitative benefit of incarceration, while Marvel and Moody estimated the total benefit of incarceration (including deterrence), these studies are not perfectly in agreement-unless there is no deterrent effect to incarceration. Nonetheless, these findings are broadly consistent with the view of James Q. Wilson that the elasticity of crime with respect to incarceration is between 0.10 and $0.20 .^{29}$

Although the consensus estimate of the elasticity of crime with respect to incarceration has been roughly 0.15 , recent work by Steven Levitt argues that the true elasticity may be substantially higher, in the neighborhood of 0.3 or greater. ${ }^{30}$ The econometric problem in trying to estimate the effect of incarceration on crime is that, even though more incarceration presumably lowers crime, more crime tends to increase the amount of incarceration. Given this simultaneity problem, ordinary least squares regression will tend to understate the true effects of increased incarceration. Levitt corrects for this bias by using prison overcrowding litigation in federal courts to identify the true effect of incarceration on crime. Successful overcrowding lawsuits result in court orders that limit incarceration levels (and thus effect crime), but by assumption, the amount of crime does not influence prisoner overcrowding litigation. ${ }^{31}$ Levitt's instrumental variables approach thus offers a potential solution to the problem of simultaneity bias: his results suggest that many crimes increase substantially in the aftermath of a court order imposing a cap on the prison population.

Levitt's paper is unusually creative and well constructed. Nevertheless, his findings raise several questions. First, it is possible that his instrument (prison overcrowding litigation) is not truly exogenous. Indeed, just as crime increases prison populations, increased prison populations induce

lation need not be biased. Conceivably, however, the states that most improved their reporting, thereby elevating the recorded magnitude of crime, were those most concerned with the issue of crime, because the rates of crime either were traditionally high or were rising sharply. These possible links between increased recording of crime and high or rising crime rates or new get-tough attitudes could bias the estimated effect of increased incarceration in either direction.

${ }^{28}$ Id at 133.

29 James Q. Wilson, Prisons in a Free Society, 117 Pub Interest 37, 38 (Fall 1994).

${ }^{30}$ Steven Levitt, The Effect of Prison Population Size on Crime Rates: Evidence from Prison Overcrowding Litigation, 111 Q J Econ 319 (1996).

${ }^{31}$ Levitt uses twelve states that have experienced system-wide restraints imposed by federal courts: Alabama, Alaska, Arkansas, Delaware, Florida, Mississippi, New Mexico, Oklahoma, Rhode Island, South Carolina, Tennessee, and Texas. 
more prisoner litigation. Although Levitt tests for this problem, the available statistical tests are themselves subject to criticism. ${ }^{32}$ Second, other attempts to estimate the elasticity of crime with respect to incarceration that use a similar approach-utilizing exogenous limits on prison capacity as an instrument for incarceration risk-have generated estimates that are much more in line with the consensus view. ${ }^{33}$ Finally, some anomalies seem to exist in the findings. For example, the only two statistically significant crime-specific elasticities were for robbery (an elasticity of 0.7 ) and burglary (roughly 0.40). All else being equal, therefore, a 10 percent increase in incarceration should lead to a 7 percent reduction in robbery and a 4 percent reduction in burglary. If the forces that generate burglaries and robberies are roughly similar, robberies should therefore fall faster than burglaries during periods when the prison population was rising sharply. But during a period when the rate of incarceration in the United States tripled (1973-91), robbery, the crime with the highest elasticity, grew by 5.2 percent, while burglary fell by 19 percent. Moreover, for the crime with the best available data-murder-Levitt finds that his instrumental variables estimate is almost identical to the ordinary least squares estimate that the elasticity with respect to incarceration is roughly .15 . Since by a large margin murder is the most socially costly crime, the overall weighted average elasticity will be shifted toward .15 even if for other costly crimes the elasticity is greater than 15 .

In sum, while Levitt's important work suggests that the elasticity of crime with respect to incarceration could well be as high as 0.3 , our sense is that this is a high-end estimate. Nonetheless, we explicitly consider a range of elasticities in our subsequent analysis, so that the effect of the differing estimates in this one parameter can be clearly identified.

\section{Crime Reduction through Social Programs}

While it is not easy to classify the numerous social interventions that are intended to or might in fact reduce crime ${ }^{34}$ we consider the crime-reduction benefits associated with the following social programs:

32 James Heckman, Instrumental Variables: A Study of Implicit Behavioral Assumptions Used in Making Program Evaluations 32 J Human Resources 441 (1997). On its face, Levitt's finding that prison population growth was substantially higher prior to the filing of prison litigation than it was in states that had no such litigation may suggest that increased crime can lead to increased incarceration, which then can generate prison litigation.

${ }_{33}$ Daniel Nagin, Crime Rates, Sanction Levels and Constraints on Prison Population, 12 L \& Socy Rev 341 (1978); Robert Sampson, Crime in Cities: The Effects of Formal and Informal Social Control, in Albert J. Reiss, Jr., and Michael Tonry, eds, 8 Crime and Justice: A Review of Research 271 (1986).

${ }^{34}$ For example, one might want to consider the Armed Forces a kind of social program. After all, they do claim to provide discipline and teach valuable skills, which might have a 
a) preschool and early childhood education/counseling;

b) family-based therapy (directed at families with children who pose unusual discipline problems);

c) 'treatment" programs for juvenile delinquents; and

d) labor market interventions, designed to remedy lapses in prior education and/or bolster job skills. ${ }^{35}$

Table 2 summarizes the results from a number of these programs ${ }^{36} \mathrm{Un}$ fortunately, while some programs for preventing crime do seem promising, most have been evaluated only in small-scale or pilot projects or over relatively short periods of time. Many of the evaluation studies are subject to various methodological problems. And many programs were not evaluated using an economic methodology that allows one to calculate their costs and benefits, which means that, even if they were "effective" - that is, if they can be shown to have a meaningful effect on criminal behavior-it is often unclear whether the effect is large enough to justify the cost of the program.

\section{A. Early-Childhood and Family Interventions}

\section{Program Characteristics}

Table 2 outlines the experience with four successful early childhood intervention programs, as well as the disappointing Head Start program. ${ }^{37}$ The

crime-reducing effect. Should various prison-like institutions, ranging from halfway houses to group therapy, be considered social programs, or are they more like incarceration? The distinctions among these alternatives can at times be somewhat arbitrary.

${ }^{35}$ Note that there is considerable overlap among these technologies. For example, the Job Corps not only teaches vocational skills, it also explicitly attempts to shape participants' values, stressing the importance of a "good attitude" in determining labor market success (Sar Levitan and Frank Gallo, A Second Chance: Training for Jobs 123-55 (1988)). This begins to look rather like some kind of therapy. Similarly, the preschool programs that successfully influenced children's behavior also "taught" parenting skills to their families.

${ }^{36}$ Caution is needed in drawing conclusions about the efficacy of a small number of successful programs amid a large number of unsuccessful ones. Consider 100 programs, none of which has an actual effect but whose performance is measured subject to random error. By chance, we would expect to observe five programs that appear to work with a 95 percent probability (assuming a one-tailed test). Selecting the most effective five would make it seem as if we had identified some promising interventions, when in fact all we had done is identified five lucky draws. This fact suggests that follow-up studies should be performed in the wake of encouraging findings and that particular attention should be paid to characteristics that distinguish the successful from the unsuccessful programs. If such characteristics can not be identified, our confidence in the allegedly successful programs should be lowered.

${ }^{37}$ For a more extensive literature review and analysis, on which we rely in the following discussion, see Hirokazu Yoshikawa, Prevention as Cumulative Protection: Effects of Early Family Support and Education on Chronic Delinquency and Its Risks, 115 Psychological Bulletin 2854 (1994). 
TABLE 2

Summary Data on Crime Prevention Programs

\begin{tabular}{|c|c|c|c|c|c|c|c|c|c|}
\hline Study & Population & Intervention & Duration & Evaluation & Quality & Size & Measures $^{\mathrm{a}}$ & Results & $\operatorname{Cost}(\$)^{b}$ \\
\hline \multicolumn{10}{|l|}{ Therapeutic programs: } \\
\hline $\begin{array}{l}\text { Oregon Social } \\
\quad \text { Learning Center }\end{array}$ & $\begin{array}{l}\text { Families with } \\
\text { socially } \\
\text { aggressive } \\
\text { children, } \\
\text { age 3-12 } \\
\text { years }\end{array}$ & $\begin{array}{l}\text { "Parent Training } \\
\text { Therapy" } \\
\text { ("time outs," } \\
\text { and so on) }\end{array}$ & $\begin{array}{l}\text { Average } 17 \text { hours } \\
\text { therapy } \\
\text { (between } 4 \text { and } \\
48 \text { hours) }\end{array}$ & $\begin{array}{l}\text { Random assignment to } \\
\text { experiment versus } \\
\text { other therapy. Pre- } \\
\text { post differences, } \\
\text { evaluated at termi- } \\
\text { nation of therapy }\end{array}$ & Good & 19 families & $\begin{array}{l}\text { Parent reports plus } \\
\text { detailed observa- } \\
\text { tion of family inter- } \\
\text { actions }\end{array}$ & $\begin{array}{l}\text { Controls fell from } .89 \\
\text { to } .74 \text { aversive acts/ } \\
\text { minute. Experi- } \\
\text { mentals fell from } \\
.92 \text { to } .32^{\mathrm{d}}\end{array}$ & 450 \\
\hline \multicolumn{10}{|l|}{$\begin{array}{c}\text { Early childhood/fam- } \\
\text { ily programs: }\end{array}$} \\
\hline Perry Preschool ${ }^{\mathrm{e}}$ & $\begin{array}{l}\text { Poor, black, } \\
\text { low-IQ } \\
\text { children }\end{array}$ & $\begin{array}{l}\text { Piagetian orien- } \\
\text { tation. Weekly } \\
\text { in-home coun- } \\
\text { seling, with } \\
\text { parent. } \\
\text { Student/ } \\
\text { teacher ratio } \\
5: 1 . \text { Highly } \\
\text { trained teach- } \\
\text { ers, staff }\end{array}$ & $\begin{array}{l}\text { Classes } 12.5 \\
\text { hours/week, } \\
\text { over } 2 \text { years; } \\
\text { in-home } 1.5 \\
\text { hours/week } \\
\text { ( } 60 \text { counsel- } \\
\text { ing weeks). } \\
\text { Total } 840 \\
\text { hours in pro- } \\
\text { gram }\end{array}$ & $\begin{array}{l}\text { Random assignment to } \\
\text { experiment or no } \\
\text { preschool, with lon- } \\
\text { gitudinal follow-up }\end{array}$ & Good $^{f}$ & 123 children & $\begin{array}{l}\text { No. of arrests by } \\
\text { age } 19\end{array}$ & $\begin{array}{l}31 \% \text { of experimentals, } \\
51 \% \text { of controls had } \\
\text { been arrested. }{ }^{\mathrm{g}} 12 \% \\
\text { versus } 25 \% \text { arrested } \\
\text { more than } 3 \text { times, } \\
42 \text { versus } 80 \text { arrests } \\
\text { for nonminor } \\
\text { crimes }\end{array}$ & $14,800^{\mathrm{h}}$ \\
\hline Syracuse Preschool' & $\begin{array}{l}\text { Poor families } \\
\quad \text { (income }< \\
\$ 18,500 \text { ) } \\
\text { education } \\
<\text { high } \\
\text { school, and } \\
\text { so on }\end{array}$ & $\begin{array}{l}\text { Family develop- } \\
\text { ment (ther- } \\
\text { apy, education } \\
\text { for kids and } \\
\text { parents). } \\
\text { Highly trained } \\
\text { teachers, staff }\end{array}$ & $\begin{array}{l}5 \text { years, from pre- } \\
\text { natal through } \\
\text { age } 5 \text {, includ- } \\
\text { ing day care, } \\
\text { preschool, and } \\
\text { so forth }\end{array}$ & $\begin{array}{l}\text { Compared with } \\
\text { "matched" control } \\
\text { children,, follow-up } \\
\text { until age } 15\end{array}$ & Fair & $\begin{array}{c}119 \text { fami- }^{-} \\
\text {lies }^{k}\end{array}$ & $\begin{array}{l}\text { Problems with proba- } \\
\text { tion department and } \\
\text { numerous other } \\
\text { measures }^{1}\end{array}$ & $\begin{array}{l}6 \% \text { of experimentals, } \\
22 \% \text { of controls had } \\
\text { probation files. Con- } \\
\text { trols' offenses were } \\
\text { much more severe }\end{array}$ & $42,125^{n}$ \\
\hline
\end{tabular}




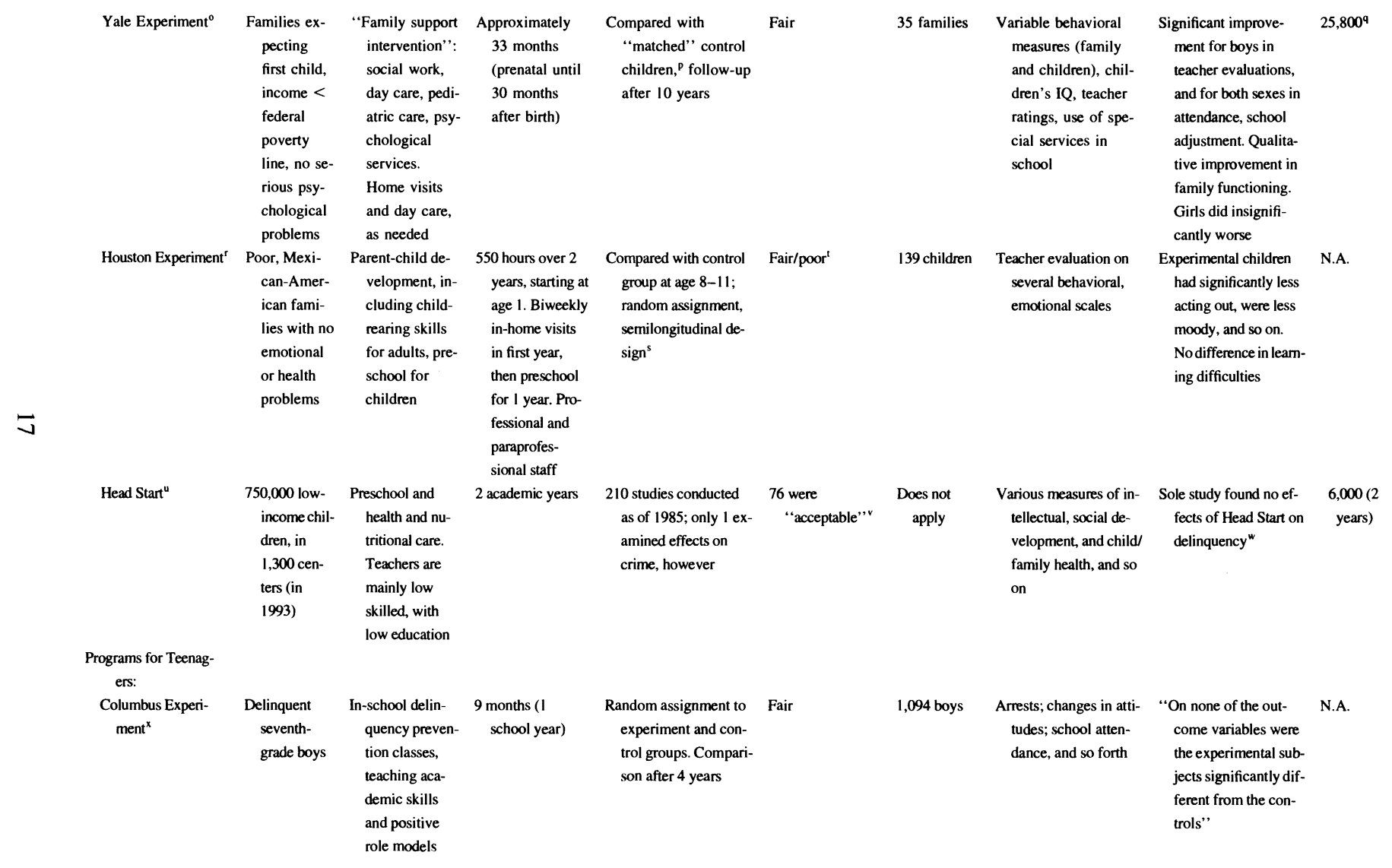


TABLE 2 (Continued)

\begin{tabular}{|c|c|c|c|c|c|c|c|c|c|}
\hline Study & Population & Intervention & Duration & Evaluation & Quality & Size & Measures ${ }^{\mathbf{a}}$ & Results & $\operatorname{Cost}(\$)^{b}$ \\
\hline Job Corps ${ }^{y}$ & $\begin{array}{l}\text { Economically } \\
\text { disadvan- } \\
\text { taged 16- } \\
21 \text {-year- } \\
\text { olds } \\
\text { (mostly } \\
\text { male) }\end{array}$ & $\begin{array}{l}\text { Educational and } \\
\text { vocational } \\
\text { training in res- } \\
\text { idential setting }\end{array}$ & 7 months & $\begin{array}{l}\text { Comparison between } \\
\text { corps members and } \\
\text { similar group of } \\
\text { nonenrollees. } \\
\text { Econometric con- } \\
\text { trol for observed } \\
\text { and unobserved dif- } \\
\text { ferences between } \\
\text { groups. 4-year fol- } \\
\text { low-up }\end{array}$ & Good & 5,100 youth & $\begin{array}{l}\text { Self-reports of arrests, } \\
\text { corrected for under- } \\
\text { reporting }\end{array}$ & $\begin{array}{l}\text { Corps members aver- } \\
\text { aged approximately } \\
290 / 100,000 / \text { year } \\
\text { fewer murders than } \\
\text { controls; about } 620 / \\
100,000 \text { fewer rob- } \\
\text { beries; } 470 / 100,000 \\
\text { fewer burglaries }^{z}\end{array}$ & $12,100^{2 \mathrm{aa}}$ \\
\hline $\begin{array}{l}\text { Quantum Opportuni- } \\
\text { ties Program } \\
(\mathrm{QOP})^{\text {bb }}\end{array}$ & $\begin{array}{l}108 \text { ninth- } \\
\text { grade stu- } \\
\text { dents from } \\
\text { families on } \\
\text { public } \\
\text { assistance, } \\
\text { in } 5 \text { cities }\end{array}$ & $\begin{array}{l}\text { Counseling }{ }^{\mathrm{cc}} \\
\text { education, } \\
\text { community } \\
\text { service, and } \\
\text { development } \\
\text { activities. } \\
\text { Students paid } \\
\text { (modest } \\
\text { amounts) for } \\
\text { participation } \\
\text { and for goal } \\
\text { achievement }\end{array}$ & $\begin{array}{l}4+\text { years, } 750+ \\
\text { hours per year, } \\
\text { for students } \\
\text { who com- } \\
\text { pleted full } \\
\text { range of activi- } \\
\text { ties }\end{array}$ & $\begin{array}{l}\text { Comparison between } \\
\text { QOP and controls, } \\
\text { with random } \\
\text { assignment }\end{array}$ & Good $^{\text {dd }}$ & $\begin{array}{l}219 \text { youth } \\
\text { (108 con- } \\
\text { trol, } 111 \\
\text { experimen- } \\
\text { tal) }\end{array}$ & $\begin{array}{l}\text { Self-reports, "No. of } \\
\text { times in trouble } \\
\text { with police in last } \\
\text { year" }\end{array}$ & $\begin{array}{l}87 \% \text { of } 79 \text { controls } \\
\text { had no trouble with } \\
\text { police in past year, } \\
8 \% \text { had } 1 \text { incident, } \\
5 \% \text { had }>1 \text {. For } 79 \\
\text { QOP participants, } \\
\text { figures were } 94 \% \text {, } \\
6 \% \text {, and } 0 \%\end{array}$ & $10,600^{\mathrm{ee}}$ \\
\hline
\end{tabular}

NoTE.-N.A. = not available. Sources for information in table notes can be found in article notes.

a Whe direct measures of delinquency (arrests records, and so forth) were part of a study, we concentrate on these. Many studies also used other attitudinal and behavioral measures, ranging from school attendance to teacher evaluations to measures of parental attachment to their child.

${ }^{b}$ Per participant, for the entire program, in 1993 dollars. Where possible, the costs are in discounted present value, at $3 \%$ per year, compounded monthly. We have assumed that the total cost is divided over the program length in equal monthly increments.

${ }^{c}$ Eugene, Oreg. (1980). See Gerald R. Patterson, Patricia Chamberlain, and John B. Reid, A Comparative Evaluation of a Parent-training Program, 13 Behavior Therapy 638 (1982). See also Patterson and Stoolmiller (cited in note 49).

' Direct observation measure; differences in pre-post between experimental and controls are significant at the 5\% level. Longer-term effects of parent therapy on parental behavior and of parental behavior on time to first arrest have also been demonstrated (Patterson and Stoolmiller (cited in note 49)), but no direct measures of the long-term effects of parent therapy are yet available.

e Ypsilanti, Mich. (1962-67). See Berrueta-Clement et al (cited in note 42) and Lawrence J. Schweinhart and David P. Weikart, The Effects of the Perry Preschool Program on Youths through Age 15-a Summary, in The Consortium for Longitudinal Studies, As the Tree Is Bent . . Lasting Effects of Preschool Programs (Erlbaum 1983). 
' Program has been carefully scrutinized, and some questions raised about the randomness of assignments (H. Spitz, Were Children Randomly Assigned in the Perry Preschool Project? 48 (8) Am Psych 915 (August 1993)). However, the consensus seems to be strongly in favor of the study's evaluation techniques. See, e.g., W. Steven Barnett and Colette M. Escobar, The Economics of Early Educational Intervention: A Review, 57 Rev Educ Res 643 (1987); David F. Farrington, Schools and Delinquency Prevention, 6 Today's Delinquent 71 (1987).

8 Berrueta-Clement et al (cited in note 42), pp. 63-69. Difference is significant at the $2 \%$ level.

" Cost for 2 years. Note that evaluation suggested that 1 year is as effective as 2 , so the "potential" cost is $\$ 7,400$. Also, since the program was not designed specifically to reduce crime, and since net benefits were actually positive, the true social cost of this program could plausibly be given as $-\$ 37,780$ (BerruetaClement et al (cited in note 42), table 26, p. 90).

i Syracuse, N.Y. (1970-75). See Lally et al (cited in note 44).

j At age 3, experimental children were matched with controls with regard to sex, ethnicity, birth order, age, family income, family marital status, mother's age, and mother's education.

k 108 families started the experimental program; 82 completed the full 5 years; 74 of the matched controls remained in sample through age 5 . After 9 years, 65 experimentals (79 percent) and 54 controls ( 73 percent) were used in the follow-up sample.

Based on court and probation department records.

${ }^{m}$ No tests for statistical significance were presented, but the differences look impressive.

" Our estimate, assuming that the cost per month is the average of the Yale and Perry programs. The program lasts for 60 months. We discount at $3 \%$ per year, compounded monthly. Peter Mangione, a coauthor of the original study, suggests a program cost of about $\$ 2,500$ per year in 1970 dollars, which translates into a discounted present value of $\$ 43,300$ in 1993 dollars, using our methods. Phone conversation with Peter Mangione, Far West Regional Laboratory, January 18 , 1995.

o New Haven, Conn. (1968-70). See Victoria Seitz et al, Effects of Family Support Intervention: A Ten-Year Follow-Up, 56 Child Development 376 (1985).

${ }^{\mathrm{p}}$ Control children were drawn from the same population as the experimentals, but at the conclusion of the experiment. No case-by-case matching.

q Using 1971 as base year. Reflects our discounting of expenditures over the 30 months of the project, at 3\% per year.

${ }^{r}$ D. Johnson and T. Walker, Primary Prevention of Behavior Problems in Mexican-American Children, 15 Am J Community Psych 375 (1987).

s The experiment was run in cohorts. The newest and oldest cohorts were evaluated at the same time, so the time elapsed since participation in the program varied across cohorts, ranging from 4 to 7 years old.

' Dropout rates of $38 \%$ in control and $48 \%$ in experimental groups. Comparison of drop and stay families for control and program groups allegedly revealed no group differences (Dale L. Johnson and James Breckenridge, The Houston Parent-Child Development Center and the Primary Prevention of Behavior Problems in Young Children, 10 Am J Community Psych 305, 309 (1982)), but no evidence is provided.

"Nationwide. See Haskins (cited in note 41).

$\checkmark$ R. H. McKey et al, The Impact of Head Start on Children, Families, and Communities (Dept of Health and Human Services No. OHD 85-31193, U.S. Government Printing Office, 1985).

${ }^{w}$ McDonald and Monroe (cited in note 45) compared 94 children in Head Start with 60 nonprogram participants. By grade 12 , 17\% of each had been referred to juvenile courts.

× Columbus, Ohio (1963-66). See Walter C. Reckless and Simon Dinitiz, The Prevention of Juvenile Delinquency: An Experiment (Ohio State University Press 1972).

${ }^{y}$ Nationwide (1977). See Long et al (cited in note 63); Mallar et al (cited in note 63); and Levitan and Gallo (cited in note 35).

${ }^{z}$ These numbers, especially those for murder, seem implausibly high. The murder rate for black males aged 15-24 (the major constituency in the Job Corps) is about $70 / 100,000$. If corps members committed no murders at all, the control group would have to have committed murders at a rate four times the average for young black males as a whole.

aa Since the Job Corps was not specifically designed to reduce crime, and since the net benefits of the program were actually positive, it is plausible to argue that the true net social costs of the program are actually $-\$ 5,550$. Even excluding benefits attributable to lower murder rate, the program still has a positive net benefit of $\$ 2,050$.

bb Philadelphia, Oklahoma City, San Antonio, Saginaw, Mich., and Milwaukee (1989-93). See Hahn (cited in note 50) for details. Note that the Milwaukee site was abandoned because the program disintegrated there.

cc Students were intensively supervised by a single counselor who devoted considerable effort to monitoring their progress and coaxing them into doing better.

dd See text for some possible flaws in the evaluation strategy.

ee Total cost of $\$ 1.12$ million for approximately 100 youth. 
successful programs share three characteristics. First, they begin their interventions with very young children-starting before birth in the case of the Syracuse and Yale experiments, and in all cases before age $4 .^{38}$ Unlike Head Start, moreover, the successful projects involved the child's family in counseling or therapy that accompanied the preschool or day care offered in the program. Thus, the successful programs attempted not only to teach cognitive and emotional development ${ }^{39}$ but also to buttress family relationships by teaching basic child care skills and techniques for effective discipline, working with both parents and children. Hirokazu Yoshikawa refers to this as an "ecological" approach, emphasizing the totality of a child's life circumstances and the importance of interaction between family behavior (such as how and when children are disciplined), the child's cognitive skills, and his ${ }^{40}$ social environment.

Finally, the successful programs were small scale, high quality, and high cost. Unlike Head Start-which enrolls about 700,000 preschool children a year and has had millions of students over its 3-decade lifetime-the experimental programs have total enrollments measured in the double or triple digits. Again, unlike Head Start, the programs were staffed by large numbers of highly trained professionals, although many also made use of paraprofessionals. ${ }^{41}$ Higher teacher/student ratios, better-trained staff, longer program length, ${ }^{42}$ and the addition of in-home counseling make the cost of the Perry program, for instance, almost 2.5 times that of the typical Head

${ }^{38}$ The importance of early life intervention is consistent with the results in Adrian Raine et al, Birth Complications Combined with Early Maternal Rejection at Age 1 Year Predispose to Violent Crime at Age 18 Years, 51 Archives General Psych 984, 988 (1994). This careful longitudinal study concludes that boys who experienced medical complications at birth in combination with weak maternal affection were substantially more likely to be involved in violent crime by age 18 .

${ }^{39}$ For an extended description of the Perry Preschool curriculum, see Mary Hohmann et al, Young Children in Action: A Manual for Preschool Educators (The Cognitively Oriented Preschool Curriculum) (1979). The schools varied in the extent to which they emphasized different aspects of education.

${ }^{40}$ Since males account for the vast majority of delinquency and crime, we will use the masculine pronoun throughout.

${ }^{41}$ By contrast, "70 percent of Head Start staff are from low-income families similar to those from which its children come." Ron Haskins, Beyond Metaphor: The Efficacy of Early Childhood Education, 44 Am Psychologist 274, 281 (1989). While this may be desirable in terms of community involvement, it does not seem effective in producing significant improvements in the life chances of the children enrolled in the program.

${ }^{42}$ The successful programs lasted for at least 2 years and, in some cases, considerably longer. The first cohort in the Perry Preschool experiment may be an exception: these children participated for only 1 year and apparently have done as well as those who had the full 2-year program. John R. Berrueta-Clement et al, Changed Lives: The Effects of the Perry Preschool Program on Youths through Age 19, at 90 (1985). However, the sample size was so small as to cast some doubt on this finding. 
Start program. The Yale program was almost 4.5 times as costly as a typical 2-year spell in Head Start, and we estimate that the Syracuse program was roughly seven times as expensive as 2 years in Head Start.

\section{Outcomes}

The successful experimental programs produced lasting gains in socialization (for example, getting along with classmates, fighting), school functioning (attendance, need for special education, repeating a year of school), self-esteem, and family functioning. Unfortunately, they did not seem to produce lasting improvements in IQ or other measures of cognitive functioning. As with Head Start, they did manage to achieve temporary gains in cognitive ability, but in all cases these gains faded with time.

Of the preschool programs we have been able to discover, only the Perry and Syracuse evaluations looked beyond general behavioral or attitudinal indicia to examine effects on actual delinquency. Both found that preschool significantly reduced involvement with juvenile justice authorities. By age 19,40 percent fewer of the experimental group in the Perry project had been arrested at least once; 50 percent fewer had been arrested more than twice, and a far greater proportion of those arrested had been arrested for minor crimes. ${ }^{43}$

The Syracuse results, while not as well documented, are similarly impressive in magnitude. ${ }^{44}$ The program appears to have lowered by more than 70 percent the proportion of children who had been processed by the county probation department. Moreover, among those with probation records, the program children committed markedly less-severe offenses and had substantially less-frequent contact with the juvenile authorities.

By contrast, the available evidence does not demonstrate any delinquencyreduction effect for Head Start. As Ron Haskins notes in his survey of the Head Start evaluation literature, only a single, unpublished study even attempted to examine the long-term effects of Head Start on criminal behavior. That study found that participation in Head Start had no effect on

${ }^{43}$ These differences are based on juvenile justice system records, not on self-report data, and are statistically significant.

44 The Syracuse study seems also to have more serious problems with attrition and turnover than did the Perry project, which may raise questions about its apparent effectiveness. For example, 25 percent of the experimentals and 31 percent of the controls quit during the course of the experiment itself; an additional 21 percent of the remaining experimentals and 27 percent of the controls could not be located for the follow-up sample 9 years after the program ended (J. Ronald Lally, Peter L. Mangione, and Alice S. Honig, The Syracuse University Family Development Research Program: Long Run Impact of an Early Intervention with Low-Income Children and Their Families 15 (1987)). 
adolescent delinquency. ${ }^{45}$ Moreover, Haskins's survey reports that numerous studies have found no evidence of long-term effects of Head Start on intellectual performance or "socioemotional functioning" and virtually no effect on measures of life success such as teen pregnancy, welfare participation, and employment. ${ }^{46}$ In sum, there are substantial reasons for concern about the investment value of Head Start, although it may well provide consumption benefits to disadvantaged children.

\section{B. Family Therapy}

The Oregon Social Learning Center has had considerable success with its version of parent-oriented behavior therapy (Parent Training Therapy, or PTT) in reducing "aversive" behavior of even severely socially maladjusted children. By teaching parents how to effectively discipline their children-through the consistent use of nonviolent punishments for misbehavior-the center staff have been able to document substantial improvements in child behavior. Since these improvements have been demonstrated under ideal experimental conditions (random-assignment, blind evaluation, prepost differences), albeit with relatively small samples, the studies seem quite convincing. ${ }^{47}$

While the short-term effects of PTT described in Table 2 are impressive, it is less clear whether PTT can actually influence behavior over the long run $^{48}$ and whether it can deter actual delinquent behavior (arrests, crimes

${ }^{45}$ Haskins (cited in note 41), citing M. S. McDonald and E. Monroe, A Follow-up Study of the 1966 Head Start Program (unpublished manuscript, Rome, Ga., Public Schools, no date).

${ }^{46}$ Haskins, at 278 (cited in note 41 ). Haskins notes that there are two kinds of selection effects that are potentially important and have been ignored in most studies of the program. Program managers deliberately select the worst-off among those eligible for the program, so comparisons between participants and those on the waiting list will tend to be biased against Head Start. Parents also decide whether to enroll their child in Head Start, some other preschool program, or no preschool at all.

In a recent paper, Janet Currie and Duncan Thomas find significant, persistent effects of Head Start participation on test scores for white and Hispanic children (though not for blacks) and significant effects of participation on indicators of overall health (for example, height) for blacks (though not for whites). Janet Currie and Duncan Thomas, Does Head Start Make a Difference? 85 Am Econ Rev 341 (1995). They utilize a large sample and employ an elegant procedure to correct for selection effects. These findings suggest that the vast array of studies indicating the lack of value in Head Start may be unduly pessimistic.

47 Other kinds of therapy are surveyed in Alan E. Kazdin, Treatment of Antisocial Behavior in Children: Current Status and Future Directions, 102 Psychological Bulletin 187, 191 (1987), which concludes that Parent Training Therapy is "one of the most promising treatments for conduct disorders.'

${ }^{48}$ C. G. Baum and R. Forehand, Long Term Follow-Up Assessment of Parent Training by Use of Multiple Outcome Measures, 12 Beh Therapy 643 (1981), demonstrates that improvements in behavior can be sustained up to 4.5 years after the cessation of therapy. 
committed), as opposed to so-called aversive acts (such as hitting siblings or being abusive to parents) ${ }^{49}$ Since the families undergoing PTT have children with serious behavioral problems between 3 and 12 years old, who are still mostly too young to be committing serious acts of delinquency, the ability of PTT to reduce crime over an extended period in a broader, more heterogeneous population remains an open question.

Nonetheless, if PTT does turn out to have a significant effect on delinquency, it would appear to be an extremely efficient means of crime prevention-at $\$ 450$ per child, it costs only a small fraction of the expense of the intensive interventions (preschool plus family counseling) discussed earlier.

\section{Therapeutic Interventions for High-Risk Adolescents}

The Quantum Opportunities Program (QOP) could be described as an intensive counseling program for low-income, ninth- to twelfth-grade students. ${ }^{50}$ The program operated in five sites, each run by local affiliates of a community-based organization. Participants were "guaranteed up to 250 hours of education [tutoring, help with homework], 250 hours of development activities [life/family skills, college or job planning] and 250 hours of service [community service projects, jobs] each full year from the ninth grade through high school graduation for in-school youth, or any time for youth who may have dropped out, transferred, or even left their original neighborhoods. Students received an hourly stipend of $\$ 1.00 \ldots$. rising to $\$ 1.33$. . . . Staff also received bonus payments and incentives.", 51

Each site initially consisted of 50 students, of whom half were randomly assigned to participate in the experiment and half constituted the control group. The participants were monitored by a full-time counselor who had close, daily contact with all of them. The program cost $\$ 10,600$ per participant.

While preventing delinquency was not the project's primary concernin fact, the benefits of reduced delinquency were not even included in the

${ }^{49}$ Gerald R. Patterson and Mike Stoolmiller, The Relation of Changes in Parental Resistance and Discipline Practices to Long Term Clinical Outcome (unpublished manuscript, Oregon Social Learning Center, 1995), suggest, obliquely, that PTT can be effective in the long term at reducing actual juvenile delinquency. The authors show that a mother's discipline style has a significant effect on the date of first arrest of her child; in other work, they demonstrate that PTT can significantly influence maternal discipline style. The conclusion would seem to be that, by altering discipline style, PTT can influence the onset of juvenile delinquency. But there is no direct evidence for this proposition.

${ }^{50}$ This section draws on Andrew Hahn, with Tom Leavitt and Paul Aaron, Evaluation of the Quantum Opportunities Program (QOP): Did the Program Work? A Report on the Postsecondary Outcomes and Cost-Effectiveness of the QOP Program (1989-1993) (Brandeis University, Heller Graduate School, Center for Human Resources, 1994).

${ }^{51}$ Id at the summary. 
cost/benefit calculations - the evaluation did ask subjects whether they had been in trouble with the police in the last year and, if so, how often. ${ }^{52}$ Program participants appeared to have had fewer brushes with the police than did the control group.

There are at least three reasons to be cautious in concluding that QOP represents a useful technology for crime prevention, however. First, even though half as many of the participants in QOP reported trouble with the police as compared with the control group, the difference was only significant at the 12 percent level by our calculations. ${ }^{53}$ Moreover, the significance declines further if we include the data from the unsuccessful Milwaukee site, which the analysts dropped from their evaluation.

Second, there were wide differences in the performance across sites, which may suggest that idiosyncratic features were responsible for the successful program(s). In fact, virtually all of the treatment effect is traceable to the Philadelphia and Saginaw, Michigan, programs. ${ }^{54}$ San Antonio participants actually had more trouble with the police than the control group, and the Oklahoma City participant and control groups were essentially indistinguishable.

Finally, the delinquency data are based on self-reports, which do not seem to have been checked against police or other records. It is at least possible that the program influenced participants' willingness to admit that they had trouble with the police, rather than changing their delinquent behavior per se. Since the evaluation makes much of the fact that the treatment group had stronger community ties and more respect for authority, either explanation seems plausible. While there are several studies confirming the validity of self-report data in general, ${ }^{55}$ one must be cautious in us-

52 The evaluation was conducted in the year after the subjects graduated (or would have graduated) from high school, an age that would place them at a high risk for delinquency.

${ }_{53}$ The report presents a $p$-value of 9 percent, ostensibly using the same $\chi^{2}$ test we did. We are unable to explain the difference.

${ }^{54}$ Philadelphia was clearly the most successful site on virtually all outcome measures. Newspaper accounts suggest that the counselor in Philadelphia was particularly dedicated and energetic, which probably accounts for at least some of his unusual success. Celia Dugger, Experiment with Success-a Special Report: Guiding Hand to College for Ghetto Youth, NY Times 1 (March 9, 1995).

${ }_{55}$ See Robert Sampson, Sex Differences in Self-Reported Delinquency and Official Records: A Multiple-Group Structural Modeling Approach, 1 J Quantitative Criminol 345 (1985); M. Erickson and W. B. Smith, On the Relation between Self-Reported and Actual Deviance, 2 Humboldt J Soc Relations 106 (1974); J. A. Kulik, K. B. Stein, and T. R. Sarbin, Disclosure of Delinquent Behavior under Conditions of Anonymity and Nonanonymity, $32 \mathrm{~J}$ Consulting \& Clinical Psych 506 (1968). For the view that there is a tendency in the general population to underreport previous involvement in crime, see Travis Hirschi, M. J. Hindelang, and J. G. Weiss, The Status of Self-Report Measures, in M. W. Klein and K. S. Teilmann, eds, Handbook of Criminal Justice Evaluation 473 (1980). 
ing such data in evaluating a program that could well have had an effect on the willingness to report police encounters accurately.

In sum, while the QOP may have produced important changes in other aspects of participants' lives, the evidence for a significant effect on delinquency is not compelling.

\section{Labor Market Interventions}

\section{General Comments}

A vast array of governmental or quasi-governmental programs have tried to boost the labor market performance of young adults. These include Job Search Assistance, the Summer Training and Education Program, the Job Training Partnership Act, and so on. ${ }^{56}$ Unfortunately, the available evidence, much of which is quite rigorous, suggests that-with one exception-these programs have had little or no effect on earnings, ${ }^{57}$ employment, ${ }^{58}$ teen pregnancy,,$^{59}$ or participation in welfare. ${ }^{60}$ Since the programs were not specifically designed to reduce criminal behavior, and since they had little or no effect on the variables they were designed to influence, it seems unlikely that they would have a substantial effect in reducing criminal conduct.

Table 2 does examine one promising jobs program-the Job Corpswhich should thus be viewed against the backdrop of a series of largely unsuccessful labor market interventions by the federal government, alone or in partnership with private contractors. Although there is evidence that the Job Corps does indeed reduce criminal behavior, its performance stands out sharply from that of other programs designed to accomplish similar ends. ${ }^{61}$ It is therefore useful to consider the aspects of the Job Corps that differ from other less successful programs.

${ }^{56}$ See James J. Heckman, Is Job Training Oversold? 115 Pub Interest 91 (Spring 1994); and James J. Heckman, Rebecca Roselius, and Jeffrey Smith, U.S. Educational and Training Policy: A Re-evaluation of the Underlying Assumptions behind the "New Consensus," in Lewis C. Solomon and Alec R. Levenson, eds, Labor Markets, Employment Policy, and Job Creation (Westview, 1994), for excellent summaries of the available evidence.

57 The Job Training and Partnership Act (JTPA) raised 18-month total earnings for adult enrollees by roughly $\$ 900$; earnings for youth fell by about $\$ 300$ for women and $\$ 1,300$ for men. Heckman et al, at 41 (cited in note 56).

${ }^{58}$ Heckman et al found only a 2-5 percent increase in employment rates for JTPA enrollees compared with a control group.

${ }^{59}$ For example, the Summer Training and Education Program had no effect on high school graduation rates, pregnancy, or welfare utilization. Heckman et al, at 25 (cited in note 56).

${ }^{60} \mathrm{Id}$ at 28.

${ }^{61}$ See, for example, Statement to the Senate Labor and Human Resources Committee by Robinson G. Hollister, Jr., regarding the Job Corps, 99th Cong, 1st Sess E3056 (June 26, 1985). 


\section{The Job Corps}

1. Background. The key feature of the Job Corps is that it is a residential, 6-7 month program. The participants, who are mostly high school dropouts, are 70 percent male and 60 percent black; only 14 percent read at above an eighth-grade level. ${ }^{62}$ While participants are economically disadvantaged and presumably have a high potential for criminality, the program does not accept applicants with serious behavioral problems, so hard-core delinquents tend to be excluded. Corps members are taught vocational skills (secretarial, auto repair, and so on); they are also provided with substantial remedial education.

The Job Corps has been subjected to a series of careful economic evaluations, based on a matched sample design, with econometric controls for observed and unobserved heterogeneity. ${ }^{63}$ The results of these cost-benefit calculations suggest that the program generates social benefits (including crime reduction) in excess of its social costs, with a rate of return of about 18 percent. ${ }^{64}$ The program had a cost per enrollee of about $\$ 12,100$ in 1993 dollars. The benefits consisted of reductions in murders, reductions in other crimes, and gains in output by participants in the program; properly discounted, these benefits totaled $\$ 17,600$ per enrollee. ${ }^{65}$ In other words, the primary study on the Job Corps, which was completed in 1982, concluded that each dollar spent on the program returned \$1.46.

2. Effects on Crime. Understanding the Job Corps' effects on crime is not entirely straightforward, even given the massive amount of information in the Final Report. Column 3 of Table 3 presents the Final Report's estimate of the per capita annual reduction in certain crimes attributable to participation in the Job Corps. The authors report that these numbers are all statistically significant, ${ }^{66}$ but it is difficult to get a sense of their magnitude,

${ }^{62}$ Levitan and Gallo, at 133 (cited in note 35).

${ }^{63}$ David A. Long et al, Evaluating the Benefits and Costs of the Job Corps, $1 \mathrm{~J}$ Policy Analysis \& Mgmt 55 (1981); and Charles Mallar et al, Evaluation of the Economic Impact of the Job Corps Program: Third Follow-Up Report (Mathematica Policy Research, Inc., 1982) (hereafter, the Final Report).

${ }^{64}$ Final Report, at 261 (cited in note 63).

${ }^{65}$ Of the total benefits, roughly 40 percent came from reduction in crime of all kinds, while the remaining 60 percent came largely from additional output produced by participants in the program after graduation. If the increased output is ignored and the program is considered purely as a crime-reduction measure, its benefits are not large enough to cover its costs.

${ }^{66}$ As far as we can tell, the procedure employed in the evaluation seems to have been as follows: (1) correct the reported number of arrests to account for underreporting; (2) estimate an ordinary least squares regression using the corrected number of arrests as the dependent variable; (3) include a number of demographic variables (age, sex, and so on) and a correction for sample selection effects as explanatory variables; and (4) also include a dummy variable for participation in the Job Corps. The coefficient on this dummy is then the estimated 
TABLE 3

Estimates of the Annual Percentage Reduction in Arrests Per Participant (Treatment Effect) from Participation in the Job Corps

\begin{tabular}{|c|c|c|c|c|}
\hline & \multirow{2}{*}{\multicolumn{2}{|c|}{ CONTROL GROUP }} & \multicolumn{2}{|c|}{ JOB CORPS } \\
\hline & & & & Percentage \\
\hline & $\begin{array}{l}\text { Number of } \\
\text { Crimes } \\
\text { Committed } \\
\text { (1) }\end{array}$ & $\begin{array}{l}\text { Arrests } \\
\text { per } \\
\text { Crime* } \\
(2)\end{array}$ & $\begin{array}{l}\text { Reduction in } \\
\text { Number of } \\
\text { Arrests } \dagger \\
\text { (3) }\end{array}$ & $\begin{array}{c}\text { Reduction } \\
\text { Crime } \\
\text { in Arrests } \ddagger \\
\text { (4) }\end{array}$ \\
\hline Murder & N.A. & N.A. & .003 & N.A. \\
\hline Assault & N.A. & .175 & .001 & N.A. \\
\hline Robbery & .46 & .062 & .006 & 21.0 \\
\hline Burglary & 4.65 & .028 & .005 & 3.8 \\
\hline $\begin{array}{l}\text { Larceny and motor } \\
\text { vehicle theft } \\
\text { Weighted average }\end{array}$ & 11.45 & .023 & .041 & $\begin{array}{l}15.6 \\
12.3\end{array}$ \\
\hline
\end{tabular}

SourCES.-Col. 1: Marvell and Moody (cited in note 26), table V, p. 132. Col. 2: Spelman (cited in note 12), table 5.1, col. 4, p. 171. Col. 3: Mallar et al. (cited in note 63), table VII.6, p. 233.

NoTE.-N.A. = not available.

* The data come from surveys asking prisoners how many crimes they committed and how many times they were arrested.

$\dagger$ The authors of the Job Corps study conclude that both corps members and controls understate their actual arrests, so they inflated reported arrests by 1.7 to estimate actual arrests. The data in col. 2 are arrests per crime and are thus compatible with these adjusted data.

$\ddagger 100 \times$ col. $3 /(\mathrm{col} .1 \times \mathrm{col} .2)$.

especially since the study does not present the actual number of arrests for either the control or experimental group. Here, we try to estimate the criminality of the control group, so we can get a feel for the proportion by which the Job Corps reduced crime.

We begin our analysis by estimating the baseline number of crimes committed by the control group (col. 1 of Table 3 ). ${ }^{67}$ We can then use estimates of the probability of arrest per crime committed to ascertain the annual number of arrests experienced by the control group. ${ }^{68}$ Multiplying the num-

program effect. We aggregated these effects across the sample periods (in-program, 1-year, 2-year, and so on), then annualized to arrive at a total effect.

${ }^{67}$ We rely on Marvell and Moody's estimates of the amount of crime of various kinds committed by the marginal addition to the U.S. prison population. Marvell and Moody, at 132 , table 5 (cited in note 26). This group is presumably more prone to crime than the control sample in the Job Corps study. Thus, when we use this number in computing the denominator of the ratio of "crimes reduced by being in the Job Corps" to "crimes committed by the control group," we tend to understate the effectiveness of the Job Corps in reducing crime.

${ }^{68}$ Since the Job Corps study used self-reports of arrest, we used Spelman's comparable data, which is drawn from RAND surveys of prisoners. The implicit assumption is that any bias in the prisoner self-reports is of the same magnitude for both their number of arrests and the number of crimes committed, so that the ratio of arrests/crime is unbiased. 
ber of crimes (col. 1) by the ratio of arrests/crime (col. 2) yields a baseline estimate of the number of arrests the control group experienced. Column 4 then computes the estimated percentage reduction in arrests caused by participation in the Job Corps. ${ }^{69}$

Because our estimates of the number of arrests experienced by the control group are likely to be biased upward - since Job Corps participants are probably less criminal than the marginal prison entrant-we have probably understated the effectiveness of the Job Corps. In contrast, the Job Corps figures were based on self-reports of arrests, which we argued above is problematic when evaluating programs that may alter the willingness to admit to criminal conduct. ${ }^{70}$ Even when seen as lower bounds, however, the results in column 4 look plausible. The Job Corps appears to reduce arrests by roughly 20 percent for robbery, 15 percent for larceny and auto theft, but by only 4 percent for burglary. The weighted average reduction is 12.3 percent.

3. Caveats. On its face, the Job Corps looks like a very attractive program: an 18 percent rate of return on a social program is very unusual, and it appears to generate some significant reductions in criminal conduct not only during the period of residential living but in the subsequent 4-year period as well. However, there are some reasons for caution. First, recent reports by the Labor Department's inspector general may suggest that the program's performance has slipped since the Job Corps was last evaluated in 1982, resulting in higher costs, more dropouts, and lower job placement rates. ${ }^{71}$ Although we are skeptical about the inspector general's report, ${ }^{72}$ any assessment of the Job Corps as it currently functions, or might function in a future expanded form, should bear in mind that the program's operation and its effectiveness under different general labor market conditions may have changed in significant ways in the 15 years since the Final Report was completed. $^{73}$

${ }^{69}$ These estimates are obtained by taking the estimated arrest reduction (col. 3) as the numerator and dividing by the baseline number of arrests.

70 See text around note 55 .

71 Job Training Program Outcomes (Report No. 12-92-004-03-370, U.S. Department of Labor, Office of the Inspector General, February 11, 1992). See also Ruth Larson, Hearing Eyes Job of Job Corps, Wash Times A8 (August 10, 1994).

${ }^{72}$ For example, the inspector general complained that only 12 percent of Job Corps participants "eventually find work that matches their job skills." See U.S. Department of Labor, Office of the Inspector General (cited in note 71). But the proper way to evaluate the value of the Job Corps is to compare those in the program with those in the control group. The 12 percent figure standing alone is quite meaningless-especially since the inspector general was troubled if a Job Corps participant who was trained to do job $X$ ended up with job $Y$ (which still could be a positive outcome).

${ }^{73}$ These changes could make the program less successful today if the deteriorating labor market for low-skilled individuals renders such job training less useful, or they could make 
Second, the Final Report estimates that participation in the program reduced the murder arrest rate of Job Corps members by about 3 per 1,000 participants per year, measured over the 4.5 -year program evaluation period. While statistically significant, the effect of Job Corps participation on murder arrests seems implausibly large. Translated into the usual metric for murder rates, the estimated reduction is 290 fewer murder arrests per 100,000 participants. ${ }^{74}$

The Final Report does not reveal the actual murder rate for the control group and Job Corps participants. But assume that Job Corps participants were never arrested for murder-that is, participation reduced murder arrests by 100 percent. A reduction of 290 murder arrests per 100,000 participants could only occur if the control group had an arrest rate for murder at least this high, but this is more than four times greater than the murder rate for black males aged 15-24. In other words, these numbers could be accurate only if the control group had an implausibly high murder arrest rate and the Job Corps completely eliminated murder arrests during the experimental period. The latter prospect seems unlikely, though, since we have estimated above that the reductions for other crimes were far less dramatic: 21 percent for robbery, 3.8 percent for burglary, and 15.6 percent for larceny and motor vehicle theft.

In addition, column 3 of Table 3 indicates that, while the Job Corps resulted in three fewer murder arrests per 1,000 participants, it lowered aggravated assault arrests by only one per 1,000 participants. This again suggests that the reduction in murders attributed to participation in the Job Corps is greatly overstated because, in general, aggravated assault arrests far exceed murder arrests. $^{75}$

Although the Job Corps evaluation seems to have overstated the program's ability to reduce murders, there is at least one countervailing factor to consider. In monetizing the gains from reduced murders, the authors of the Final Report valued each human life saved at roughly $\$ 300,000$ (in 1993 dollars), which is considerably lower than most other estimates. For example, Mark Cohen ${ }^{76}$ uses a figure of $\$ 2.79$ million (1993 dollars), and

the program more successful if the increases in juvenile crime lead to a greater possibility of enjoying significant crime reduction benefits.

${ }^{74}$ At the time of the Final Report (cited in note 63), the murder rate for the United States as a whole was about $10 / 100,000$, and the murder arrest rate was only slightly lower. During the evaluation period covered in the Final Report, the murder rate for black males aged 1524, a good proxy for Job Corps participants, was about 70 per 100,000 .

${ }^{75}$ In 1992, the total estimated arrests for murder and nonnegligent manslaughter were 22,510; for aggravated assault, 507,210. Federal Bureau of Investigation, Crime in the United States 1992, annual report, at 217, table 29.

${ }^{76}$ Mark Cohen, Pain, Suffering, and Jury Awards: A Study of the Cost of Crime to Victims, 22 L \& Socy Rev 537 (1988). 
some estimates range as high as $\$ 5$ million. ${ }^{77}$ Conceivably, the overstatement in the estimated reduction in murders - the true number might well be only one-fourth the estimated number-could be precisely offset by the low estimate for the dollar value of murders prevented, which in turn might be only one-fourth the true value. In contrast, the estimated value of life in these cost-benefit estimates usually varies positively with the present value of future earnings, and the earning of potential murder victims of Job Corps participants might well be low relative to the population at large, thereby justifying the low estimate used in the Final Report. The proper means of valuing human lives in cost-benefit studies - which obviously raises intractable philosophical and ethical questions - turns out to be central to many criminal justice policy decisions.

\section{The Trade-off between Incarceration and Social Programs}

\section{A. An Overview of the Trade-off}

It is frequently noted that it costs more to house someone in prison for 1 year than it would to send them to Harvard College for the same length of time. The statement is usually followed by an admonition to spend the money up front on educating the potential criminals, making it unnecessary to send them to prison down the road. This section explores the logic of this policy prescription. In doing so, we immediately run up against two central problems. The first is the one we have already been discussing: are there programs that can actually reduce criminality? The second is the problem of targeting. ${ }^{78}$ Most crime is committed by only a small fraction of the total population. ${ }^{79}$ If we knew that there were programs that actually reduced criminality, and we knew in advance who the potential criminals

${ }^{77}$ Cohen's figure is derived from studies estimating a workers' willingness to pay for reductions in the risk of death by accepting lower wages. Using the same approach, however, the Environmental Protection Agency estimated the value of a life to be $\$ 4.8$ million (in evaluating the cost of cigarette smoking).

${ }^{78}$ The issue is related to, but broader than, the criminological debates about selective incapacitation. See, for example, Peter Greenwood, Selective Incapacitation (1984). Greenwood argues that an efficient way of using prison to reduce crime would be to sentence the criminals who commit the most crimes to the longest sentences. Moral considerations aside, the problem is largely one of identifying who the career criminals actually are. For an empirically and theoretically convincing rebuttal to Greenwood's conclusions, see Spelman (cited in note 12).

${ }^{79}$ For example, Marvin Wolfgang, Robert F. Figlio, and Torstein Sellin, Delinquency in a Birth Cohort (1972), conclude that approximately 6 percent of all males born in Philadelphia in 1945 committed 52 percent of all offenses by males born in Philadelphia in that year. In a second study looking at males born in Philadelphia in 1958, 7.5 percent of these males committed 61 percent of all the delinquent acts of that birth cohort of males. Paul Tracy, Marvin Wolfgang, and Robert Figlio, Delinquency Careers in Two Birth Cohorts 279-80 (1990). 
would turn out to be, we could target such individuals for participation in these programs. But apart from the legal and moral questions this kind of targeting raises, there is no reliable way of identifying who is likely to become a serious criminal, and certainly no way to make accurate predictions early enough to be useful in assigning 3-year-old children to preschool. The result is that any money saved by reducing the number of people in prison must necessarily be spread across a large pool of potential incarcerees, which limits the amounts available to be spent on each recipient.

The question we explore is whether the social resources that will be expended a decade or more from now on incarcerating today's youngsters could instead generate roughly comparable levels of crime prevention if they were spent today on the most promising social programs. To focus our inquiry, assume that the two choices we confront are (1) increase the prison population by 50 percent over the level in December of 1993, which seems to be the trend of current policy, or (2) maintain the December 1993 level of incarceration and spend the present value of the saved social resources on crime-reducing social programs.

Increasing the prison population by 50 percent would be expected to reduce crime by an amount equal to

$$
\Delta \text { Crime }=.5 \times \eta,
$$

where $\eta$ is the elasticity of crime with respect to the prison population. The value of $\eta$ is obviously crucial to this analysis, and, as we discussed earlier, our view is that the elasticity probably falls in the range of .15-.20, but it could be as low as .10 or as high as .30 . Using the broadest range estimates, crime will be about $5-15$ percent higher under a constant incarceration rate policy than it would be with a 50 percent higher incarceration rate, other things being equal.

The question then becomes whether channeling the social costs avoided by cutting the growth of the prison population into social spending can offset the 5-15 percent increase in crime generated by these cuts. If so, then spending - the social savings from a lower prison population on preventative social programs - would seem to be a clearly superior policy.

\section{B. Assessing the Costs}

To begin to explore the choice between the punitive and preventive strategies of crime control, it is useful to consider the trade-offs that society is implicitly making. One possibility might be to spend money on education, counseling, and treatment for youngsters from preschool through high school; alternatively, we might choose to spend these same funds on imprisoning a small but significant portion of these children several years down 
the road. The decision must be confronted for the new crop of 3.8 million 3 -year-olds rather directly. We can try to control crime through social spending over the next 15 years or by spending money on them later for commitment to juvenile detention centers or incarceration in federal and state prisons.

If we make some assumptions about the future levels of incarceration for the current group of 3-year-olds, we can compute the present value of the future costs of incarceration for this cohort. First assume that the society wished to maintain the 1993 incarceration rate ${ }^{80}$ This would imply that today's 3.8 million 3-year-olds will spend a total of about 925,000 personyears in prison ${ }^{81}$ and about 93,945 person-years committed to juvenile detention facilities. ${ }^{82}$

Table 4 reveals the present value of the future cost of incarcerating today's 3-year-olds both in juvenile detention facilities and in prison where the growth of prison population is restrained and where it is allowed to grow by 50 percent ${ }^{83}$ Choosing the no-growth policy implies that we could

${ }^{80}$ In 1993 the prison population, then numbering 925,000, was rising rapidly.

${ }^{81}$ How many different individuals from this age cohort would actually go to prison? Obviously, the answer depends on the average length of stay and the number of repeat visits to prison. For example, if the average time spent in prison were 2 years with no return visits, then we would be incarcerating 462,500 individuals from this cohort at some point in their lives. Alternatively, if the average person to be incarcerated spent 20 years in prison (perhaps over many spells), then the total number of individuals who would be imprisoned from this cohort would be 46,250 .

Although our estimate of the total cost of incarceration (which is based on the number of bodies in prison, not their identities) does not depend on this issue, we speculate that between 125,000 and 200,000 of the 3.8 million in this cohort will spend some time in prison. This estimate is based on the age distribution of the total U.S. state prison population in 1991: 21.9 percent of the prison population was under age $25,24.2$ percent were aged $25-29,21.5$ percent were aged 30-34, and 32.4 percent were 35 or older. U.S. Department of Justice, Bureau of Justice Statistics, Sourcebook, table 6.69 (1992).

As we see below, the number of individuals who, under present policies, will spend time in prison is relevant in assessing the feasibility of targeting of high-risk individuals for some form of preventive treatment. On reasonable assumptions, as many as two-thirds of the 100,000 poorest black male 3 -year-olds of today may end up in prison.

${ }^{82}$ The figure in the text represents the total number of juveniles in public and private detention facilities in 1989. Id at table 6.27. Table 6.14 of that publication reveals that the bulk of these juveniles are aged 14-18.

${ }^{83}$ These figures represent only the full cost of physical custody and lost legitimate earnings of the incarcerated population-not the cost of apprehending and convicting this population. Nor do they include the cost of supervising the large number of individuals on probation and parole. In 1990, 2.5 million individuals were on probation, and just under one-half million were on parole. Id at tables 6.1 and 6.2. Furthermore, the figures do not account for the sizable jail population. In 1991, the average daily population of jails was 422,609 . Id at table 6.31. (The costs of apprehending and convicting the prison population should be added in to weigh the prevention/incarceration trade-off, if in fact fewer arrests and convictions occur with the preventive strategy.) 
TABLE 4

The Present Value of the Future Incarceration Costs of the CurRent CoHort of 3.8 Million 3-YEAR-OLDS (Billions)

\begin{tabular}{lcc}
\hline \hline & \multicolumn{2}{c}{ Discount Rate (in \$) } \\
\cline { 2 - 3 } & 3 Percent & 4.5 Percent \\
\hline At 1993 rate of incarceration & 16.0 & 11.1 \\
At 50 percent higher rate of & & \\
incarceration & 24.0 & 16.7 \\
Difference & 8.0 & 5.6 \\
\hline
\end{tabular}

Source.-Our calculations are as described in text, assuming that the social cost of incarcerating a prisoner for a single year is $\$ 35,620$.

now spend $\$ 5.6$ to $\$ 8$ billion on today's 3-year-olds (depending on the appropriate discount rate).

Having ascertained that a 50 percent increase in future incarceration for today's 3-year-olds would cost between $\$ 5.6$ and $\$ 8$ billion (in present dollars) and that it would reduce crime by $5-15$ percent, we are now in a position to explore the costs and benefits of an alternative policy: stopping the growth in incarceration and redirecting the $\$ 5.6-\$ 8$ billion toward crime reduction programs such as preschool education or job training. Subsection $C$ below examines how much social spending we can purchase with the social resources saved by stopping the growth in incarceration. Subsection $D$ examines how much crime reduction we can expect from this amount of social spending, and discusses the conditions that must exist in order to achieve greater reductions in crime from social spending than from increased incarceration: (1) specifically, we see that the moderate (as opposed to high-end) estimates of the crime-reducing effect of incarceration are accurate; (2) we can target the social spending resources to the highest risk population; and (3) we can achieve from a widely implemented social program about half the benefits in crime reduction that have been obtained in small pilot projects. Subsections $E$ and $F$ address some practical and ethical concerns about the likelihood and advisability of such targeting and about the feasibility of securing such benefits from a major social intervention.

\section{How Much Social Intervention Can Our Diverted Resources Buy?}

Table 5 summarizes how far the resources saved from a 50 percent reduction in incarceration would go if used to fund different social programs over the lifetime of the current crop of 3-year-olds. For example, these saved resources could fund a Perry Preschool-type program for between 376,000 and 540,000 students, which is roughly $10-14$ percent of all 3- 
TABLE 5

The Crime-Reducing Social Programs We Could Buy by Keeping the Prison Population at Current levels Instead of Allowing a 50 Percent Increase Over the Next 15 Years, by the Number of Children Who Could Be SERVED (Percent of Current Cohort of 3-Year-Olds in Parentheses)

\begin{tabular}{|c|c|c|c|}
\hline \multirow[b]{2}{*}{ Program $\S$} & \multicolumn{3}{|c|}{$\begin{array}{l}\text { AsSUMPTIONS ABOUT COST SAVINGS FROM } \\
\text { REDUCED INCARCERATION }\end{array}$} \\
\hline & $\begin{array}{c}\text { Most } \\
\text { Pessimistic* }\end{array}$ & $\begin{array}{c}\text { Most } \\
\text { Optimistic } †\end{array}$ & $\begin{array}{c}\text { Optimistic, } \\
\text { and No } \\
\text { Head Start } \ddagger\end{array}$ \\
\hline \multicolumn{4}{|l|}{ Parent Effectiveness } \\
\hline \multicolumn{4}{|l|}{ Training, at } \\
\hline \$450/child & $\begin{array}{l}12.4 \text { million } \\
(326)\end{array}$ & $\begin{array}{l}17.8 \text { million } \\
(467)\end{array}$ & $\begin{array}{l}22.4 \text { million } \\
(590)\end{array}$ \\
\hline \multicolumn{4}{|l|}{ Head Start, at } \\
\hline$\$ 6,000 /$ child & $\begin{array}{l}928,000 \\
(24.4)\end{array}$ & $\begin{array}{l}1.3 \text { million } \\
(35.0)\end{array}$ & $\begin{array}{l}\text { Does not } \\
\text { apply }\end{array}$ \\
\hline \multicolumn{4}{|l|}{ Job Corps, at } \\
\hline$\$ 12,100 /$ participant $\|$ & $\begin{array}{l}696,000 \\
(18.3)\end{array}$ & $\begin{array}{l}1.2 \text { million } \\
(32.2)\end{array}$ & $\begin{array}{l}1.5 \text { million } \\
(40.6)\end{array}$ \\
\hline \multicolumn{4}{|l|}{ Perry Preschool, at } \\
\hline $14,800 /$ child & $\begin{array}{l}376,000 \\
(9.9)\end{array}$ & $\begin{array}{l}540,000 \\
(14.2)\end{array}$ & $\begin{array}{c}682,000 \\
(17.9)\end{array}$ \\
\hline \multicolumn{4}{|l|}{ Yale Program, at } \\
\hline$\$ 25,800 /$ child & $\begin{array}{l}216,000 \\
(5.7)\end{array}$ & $\begin{array}{l}309,000 \\
(8.1)\end{array}$ & $\begin{array}{c}391,000 \\
(10.3)\end{array}$ \\
\hline \multicolumn{4}{|l|}{ Syracuse Program, at } \\
\hline$\$ 42,100 /$ child & $\begin{array}{l}132,000 \\
(3.5)\end{array}$ & $\begin{array}{l}190,000 \\
(5.0)\end{array}$ & $\begin{array}{l}239,000 \\
(6.3)\end{array}$ \\
\hline
\end{tabular}

NotE.-See text for explanation of sources. Numbers have been rounded.

$*$ Savings $=\$ 5.60$ billion, or almost $\$ 1,500$ for each of the 3.8 million 3-year-olds.

$\dagger$ Savings $=\$ 8.2$ billion, or $\$ 2,200$ for each 3-year-old.

$\ddagger$ Savings $=\$ 10.3$ billion; col. $2+\$ 3,000 /$ child $\times 2$ years $\times 350,000$ children $/$ year. This amounts to $\$ 2,700$ for each 3-year-old.

$\S$ Cost data are in 1993 dollars; program expenditures have been discounted to net present value terms, where appropriate.

|| Since the Job Corps is a program designed for 17-year-olds, not 3-year-olds, the savings from reduced incarceration do not need to be discounted. Thus, the same prison closures in 2008 will generate a larger sum of money for spending on the Job Corps in 2008 than would be available for spending on 3 -year-olds today. The net present value of the program's future costs depends on the interest rate assumption: at 3 percent, the net present value of the program's cost is $\$ 8,000$.

year-olds. Alternatively, the $\$ 5.6$ to $\$ 8$ billion would enable us to spend roughly $\$ 940-\$ 1,040$ each year from age 3 through the end of high school if we targeted the money to the 500,000 3-year-olds currently supported by AFDC. The available sum per year would be about 30 percent higher if we limited it to the 350,000 3-year-olds currently enrolled in Head Start. These are not trivial amounts, but they are unlikely to generate substantial schooling gains or crime reduction. Except for the low-cost Parent Training Ther- 
apy, the programs listed in Table 5 are too expensive to provide to the entire cohort of 3-year-olds. Nonetheless, the message of the table is basically encouraging because the savings from the reduction in incarceration are sufficiently great that they could fund some promising social programs at a relatively large scale.

Even if we make the most pessimistic assumptions about how much cutting the prison population would reduce social costs, this sum would be sizeable enough to pay for 2 years of Head Start for an additional 928,000 children. This would expand the Head Start program to roughly 1.3 million 3-year-olds-about one-third of the entire cohort. Since Head Start has shown no ability to reduce crime or delinquency (nor has it given strong indication of long-term cognitive or social benefits), this would not be a wise expenditure by our criteria. In fact, it might make sense to abolish Head Start altogether and use the money to fund a super-Head Start type program for a smaller number of children. We consider this option in the last column of the table. Obviously, the more expensive and effective Perry and Yale programs have more limited potential scope, reaching only 18 percent (Perry) or 10 percent (Yale) of the 3-year-olds, even under the most optimistic assumptions. But remember the finding that about 6 percent of boys commit more than half the crime for boys of that age. As long as we are treating a significant enough portion of the high-risk population so that we are likely to capture a high proportion of that 6 percent, there is still scope for a significant reduction in crime.

The advantage of the Job Corps as a crime-fighting vehicle comes from the fact that it is a program for those aged 16-21. This implies that one may be better able to target its use to those who are most at risk to commit crime; moreover, expenditure on the Job Corps comes 13-18 years later than expenditures on preschool interventions, which lowers the present value of its cost. At present, the Job Corps currently enrolls about 60,000 people in 100 Job Corps centers located in 46 states. ${ }^{84}$ The additional resources that would be available from the reduction in incarceration, even under pessimistic assumptions, would enable this enrollment to increase by more than 10-fold, reaching about 18 percent of the cohort.

\section{Effects on Crime}

\section{Targeting Young Males}

We have just calculated how many individuals we could afford to enroll in the various types of social programs with the savings from reduced incar-

${ }^{84}$ Larson (cited in note 71). 
ceration. But how much crime reduction could we then expect to see from the different social programs? For example, the Perry Preschool program seems to have produced a 40 percent reduction in crime for those who participated in it, and we could afford to provide this program for 10-18 percent of all 3-year-olds. ${ }^{85}$ It is unrealistic to think that the small Perry Preschool program results could be replicated in such a massive social program, but our working hypothesis will be that the massive preschool intervention could reduce crime for its participants by half the amount found in the Perry program, or 20 percent.

Could the program be targeted with sufficient precision to encompass all those 3-year-old children who were destined to become the most active 6 percent of delinquents? If so, a 20 percent reduction in the crimes committed by this small group alone would reduce the cohort's overall crime by 10 percent (since these individuals commit 50 percent of all crime, and the program is assumed to reduce the number of crimes they commit by 20 percent). In other words, if we could identify and treat the worst 6 percent of delinquents and reduce their crime rate by 20 percent, our thought experiment of shifting resources from imprisonment to social programs would likely reduce crime or maintain it at the same level (unless the high-end estimate of .3 as the elasticity of crime with respect to incarceration were true, in which case the reduced incarceration would elevate crime by 15 percent, and the social spending would lead it to fall by only 10 percent).

As a matter of algebra, crime reduction will be achieved most efficiently - all other things being equal - if society pursues policies that change the criminal behavior of the highest crime group. To increase the chance that we treat the most crime-prone 6 percent, one might take cognizance of the fact that almost 93 percent of those in prison are men. ${ }^{86}$ If one assumes

${ }^{85}$ Even if this finding is correct and reproducible on a large scale-empirical issues that can only be answered in expanded pilot programs - we could only expect a 40 percent reduction in criminality if the enrollment in the expanded program were similar in potential criminality to those enrolled in the Perry Preschool. This point is developed with great sophistication (along with statistical adjustments to correct for these kinds of selection problems when estimating large-scale effectiveness) by James Heckman, Randomization and Social Policy, in Charles F. Manski and Irwin Garfinkel, eds, Evaluating Welfare and Training Programs (1992).

Even if the larger population contains a larger proportion of noncriminals, it is conceivable that the potential criminals in this population might be more amenable to treatment than those in the original experimental population. This would partially offset the problem discussed in the previous paragraph.

${ }^{86}$ In 1990, 92.6 percent of state and federal prison inmates were men. U.S. Department of Justice, Bureau of Justice Statistics, table 6.65 (cited in note 81 ).

That we want to change male criminal conduct does not necessarily imply that we should focus our spending on men, however, for two reasons. First, it might be easier to influence male behavior by changing parenting practices than by spending directed explicitly at young boys themselves. Second, the participation of young girls in, for example, the Perry Program 
that the rate of incarceration coincides with the rate of serious, violent crime, then this crime rate for men is 13.3 times the crime rate for women. ${ }^{87}$

By limiting our spending on an enriched preschool program for boys, we could afford to offer a Perry Preschool program to almost 20 percent (presumably the worst-off 20 percent) of all boys, even under the most pessimistic assumptions. Under the most favorable projections, we could provide a Perry-like program for the poorest one-fourth of all children or the poorest half of all boys. The more expensive Yale and Syracuse programs would be available to a commensurately smaller group of potential enrollees.

\section{Further Targeting: Young Black Males}

If we assume that black men, who make up 45 percent of those in prison, commit 45 percent of the serious, violent crime, then black men have a crime rate that is 12.8 times that of the remaining 94 percent of the population ${ }^{88}$ Thus, even with as crude a strategy as targeting all expenditures on 3 -year-old black boys, we can ensure that our expenditures will reach those with an expected future crime rate that is roughly 12.8 times that of the base population.

Returning to Table 5, we note that the savings from our hypothetical 50 percent reduction in incarceration is sufficient to enroll virtually all of the 295,000 3-year-old black boys in any of the social programs listed, even under the most pessimistic assumptions. ${ }^{89}$

\section{The Crime-Reduction Benefits of Selected Social Programs}

Table 6 compares the crime-reduction benefits from the various programs under different assumptions about how much money is available to be spent

might contribute in some important way to its success in altering the behavior of its male participants. Perhaps having girls as role models would be useful in teaching boys how to behave. The bottom line is that program cost doubles if one must provide benefits to both boys and girls, and therefore, one must explore whether crime reduction benefits also double if both boys and girls are funded.

${ }^{87}$ Given the assumption in the text, the following condition must hold:

$$
.5 p y c /(.5 p y c+.5 p c)=.93 \text {, }
$$

where $p$ is the total population, $c$ is the crime rate for the 50 percent of the population that is female, and $y c$ represents the crime rate of the 50 percent of the population that is male. Solving for $y$ reveals that the crime rate for men is 13.3 times that of women.

${ }^{88}$ If black men are 6 percent of the population, then $.06 p y c /(.06 p y c+.94 p c)=.45$, where $p$ is the total population, $c$ is the crime rate for the 94 percent of the population that is neither black nor male (the base population), and $y c$ represents the crime rate of black males. The value of $y=12.8$.

${ }^{89}$ The sole exception is the Syracuse program, which we estimate is so expensive that it could only be made available to about 44 percent of the 295,000 3-year-old black boys under pessimistic assumptions. Under more optimistic assumptions, 80 percent coverage for this group would become feasible, however. 


\section{TABLE 6}

Percentage Reduction in the Total Volume of Crime Hypothetically AChievable When SaVings from Reduced InCARceration Are Targeted to Programs Serving Young Black MaLes

\begin{tabular}{|c|c|c|}
\hline \multirow[b]{2}{*}{ Program } & \multicolumn{2}{|c|}{$\begin{array}{l}\text { PeRcentage Reduction } \\
\text { UNDER: }\end{array}$} \\
\hline & Worst Case* & Best Case $\dagger$ \\
\hline $\begin{array}{l}\text { Job Corps: } \ddagger \\
\text { From black males } \\
\text { From others served }\end{array}$ & $\begin{array}{l}2.8 \\
.4 \S\end{array}$ & $\begin{array}{l}5.5 \\
2.5 \|\end{array}$ \\
\hline $\begin{array}{l}\text { Total reduction in crime } \\
\text { Perry Preschool:\# } \\
\text { From black males } \\
\text { From others served }\end{array}$ & $\begin{array}{l}3.2 \\
9.00 \\
.3 * *\end{array}$ & $\begin{array}{c}8.0 \\
18.0 \\
2.5+\dagger\end{array}$ \\
\hline $\begin{array}{l}\text { Total reduction in crime } \\
\text { Syracuse Program: } \ddagger \ddagger \\
\text { From black males } \\
\text { From others served }\end{array}$ & $\begin{array}{l}9.3 \\
7.1 \\
.0 \S \S\end{array}$ & $\begin{array}{r}20.5 \\
26.1 \\
.0||||\end{array}$ \\
\hline Total reduction in crime & 7.1 & 26.1 \\
\hline $\begin{array}{l}\text { SouRCES. - Calculations are bas } \\
* \text { Cost savings are from cutting } \\
\text { is one-half as effective in large sca } \\
\dagger \text { Cost savings of } \$ 10.3 \text { billion. } \\
\text { as in original application. } \\
\ddagger 12.3 \text { percent reduction in crim } \\
\S \text { In addition to the } 295,000 \text { bl } \\
400,000 \text { others, who account for } 5 \text {. } \\
\| \text { In addition to the } 295,000 \text { blac } \\
\text { million others, who account for } 18 \\
\# 40 \text { percent reduction in crime } \\
* * \text { In addition to the } 295,000 \mathrm{~b} \\
81,000 \text { others, who account for } 1.2 \\
\dagger \dagger \text { In addition to the } 295,000 \mathrm{~b} \\
387,000 \text { others, who account for } 5 \text {. } \\
\ddagger \ddagger 70 \text { percent reduction in crim } \\
\S \S \text { The program can only be of } \\
\text { males. } \\
\|\| \| \text { The program can only be of } \\
\text { males. }\end{array}$ & $\begin{array}{l}\text { Table } 5 \text { and tex } \\
\text { on population = } \\
\text { in original expe } \\
\text { ram is equally ef } \\
\text { original experim } \\
\text { males, the progr } \\
\text { rcent of all crime } \\
\text { les, the program } \\
\text { ent of all crime. } \\
\text { articipants in ori } \\
\text { males, the prog } \\
\text { mal of all crime. } \\
\text { males, the prog } \\
\text { rcent of all crime } \\
\text { original particip } \\
\text { to } 46 \text { percent }\end{array}$ & $\begin{array}{l}\text { billion. Program } \\
\text { tt. } \\
\text { ve in large scale } \\
\text { ould also serve } \\
\text { d also serve } 1.2 \\
\text { program. } \\
\text { ould also serve } \\
\text { ould also serve } \\
295,000 \text { black } \\
295,000 \text { black }\end{array}$ \\
\hline
\end{tabular}

and how effective the programs are at reducing the criminal behavior of those who participate. In many instances, there are sufficient funds available to pay for the program for some of the 3-year-olds outside the crude target group of 295,000 black males. The table thus decomposes the total crime reduction into that caused by the changed behavior of black males and of the other recipients. 
Consider the Job Corps, which we estimated reduced crime among program participants by 12 percent in the past. Because the program is less expensive and is implemented further in the future, we could afford to enroll all blacks from the current cohort of 3-year-olds, with enough left over to pay for more than 400,000 others, even under the pessimistic assumptions about the magnitude of the available resources. If we again assume that the program would reduce crime for all participants by half of its estimated 12 percent, it would then generate a 2.77 percent $(.45 \times .12 \times .5)$ reduction in the overall level of crime from the black males who participated and an additional .4 percent reduction from the others who could be enrolled. Under these assumptions, an expanded Job Corps could not lower crime as much as the alternative policy of a 50 percent increase in the level of incarceration. Even under the most highly optimistic assumptions listed in Table 6, the Job Corps is less effective than the Perry Preschool-type intervention at reducing crime in a cost-effective manner. ${ }^{90}$

On its face, widespread adoption of the Perry Preschool program looks most promising, in large part because the initial program was deemed to have reduced crime by 40 percent. The Syracuse program is the most expensive of the three considered in the table. It also appears to be the most effective at reducing crime, although problems in the evaluation may call this finding into question. ${ }^{91}$ Under the most pessimistic assumptions, the program falls slightly short of our target 7.5 percent crime reduction standard. Under more optimistic assumptions, the program reduces overall crime rates by a dramatic 26 percent. Even though the program is relatively expensive, we could afford to enroll all of the 295,000 3-year-old black males who, it is posited, will commit 45 percent of the FBI index crime for that cohort. Assuming that a broad-based program could reduce crime among program participants by only 20 percent (that is, at half the rate of the original Perry program), the overall reduction in crime would be 9.3 percent-even under pessimistic assumptions about resource availability. In sum, halting the growth of the prison population and shifting the resources to a Perry Preschool-type program that was only one-half as effective at reducing crime as the original Perry Preschool could still reduce crime

\footnotetext{
${ }^{90}$ Note that the optimistic Job Corps estimates would only be generated if one could obtain the full 12 percent crime reduction from the full array of participants, who would then include 1.2 million nonblack males (see Tables 5 and 6). But it is questionable whether applying the Job Corps so broadly to a class of participants likely to be far different from those examined in the 1982 Job Corps assessment would generate the same amount of crime reduction.

${ }^{91}$ See note 44 above.
} 
while realizing a social savings - if the low or moderate levels of the predicted effectiveness of incarceration are most accurate. ${ }^{92}$

One cautionary note. Given the uncertainties surrounding the calculations and assumptions we have made, the numbers in Tables 5 and 6 cannot be accepted as precisely measured. But the thrust of our demonstration is compelling in that it clarifies the assumptions necessary for increased spending on social programs to generate crime reductions of the same order of magnitude as the prison spending it replaces. Moreover, the case for at least further experimentation on social programs is strengthened, we think, when we consider some additional consequences of the prevention approach.

\section{E. Prevention versus Incarceration: Some Additional Consequences}

\section{Ancillary Benefits}

The above analysis has ignored a number of social costs and benefits from the two different approaches-prevention expenditures versus incarceration expenditures. First, the prevention expenditures that we have considered generated significant benefits in addition to those stemming from crime reduction. Indeed, none of the successful programs were specifically designed as anticrime policy. Our focus on trade-offs between incarceration and social programs that leave the crime rate unchanged is thus a very conservative way of evaluating these social programs. At least some of these programs have positive net benefits evaluated on their own merits. These include better school performance for program participants, greater productivity, and greater psychological well-being for the treated individuals and their families.

Similarly, prison is likely to lower future productivity and increase psychological problems for the incarcerated individuals and their families. If the skeletal costs and benefits of the two approaches were roughly comparable, it would seem that these factors would tip the balance decidedly in favor of preventive expenditures.

92 The increase in crime from the curtailed growth in incarceration was already estimated to be about 5-15 percent. Table 6 reveals that the offsetting estimated reduction in crime from the preschool intervention would be at least 9 percent.

The aggregate crime reduction from social programs could be overstated to the extent that the replacement effect (discussed earlier with respect to incarceration) also operates when potential criminals turn away from crime. But note that, while perhaps 50,000 of the 3.8 million cohort of 3-year-olds will be incapacitated by incarceration during the cohort's peak period of criminality, at least 385,000 and possibly as many as 980,0003 -year-olds will receive the preschool intervention. Thus, the replacement phenomenon should have less scope to operate in the case of effective social interventions. 


\section{Practical and Ethical Issues in Selection}

The selection of children for participation in these programs raises some difficult moral and practical issues. It is not costless to select individuals either for preventive treatment or for incarceration, but the costs of the two approaches are different in kind and difficult to compare. ${ }^{93}$ Any program that tried to give preschool enrichment to a narrow group targeted on race and gender grounds would be controversial and possibly unconstitutional. Why should girls be excluded from a program that can produce a substantial improvement in life chances simply because they tend to commit less crime than boys? What about poor Hispanics? Poor whites?

Another serious concern is that a focus-whether explicit or impliciton "treating" certain demographic groups may stigmatize them as inherently crime-prone, with adverse consequences. For example, the National Institutes of Health is currently conducting a violence prevention project involving more than 8,600 children in 16 Chicago area schools. The parents of children who are enrolled in the program are told that the children have been selected for "leadership training." One of the principal investigators in the project admitted the deception in that "we don't say to people that the real reason we're funded is because we believe these kids are at high risk for antisocial behavior." 94

Selection raises practical concerns as well. Selection on gender grounds is especially difficult since one cannot rely on geographical segregation to screen out young girls or women, as might be possible for selection on other grounds. Moreover, since all of the preschool programs we discuss were implemented coeducationally, a plan to treat only boys would presumably alter the character of the programs, perhaps in a way that might impair their effectiveness. For example, teaching young boys to cooperate with or respect young girls might be an important component in some of the programs we described, and this component might be undermined if enrollment were restricted to boys only. It is at least conceivable, however, that even

${ }^{93}$ Even though there is a sense in which criminals "select themselves" into incarceration, there are still significant selection costs involved, albeit no fear of moral hazard. The police must catch and the criminal justice system must prosecute and convict criminals before they can be incarcerated. These expenses need not be factored in to the costs of incarceration, however, if changes in the incarceration rate come purely from reductions in the likelihood of incarceration conditional on arrest and conviction.

${ }_{94}$ Sheryl Stolberg, Nipping Violence in the Bud, LA Times A1 (December 31, 1993). One might argue that the current criminal justice system, which imprisons black males at nearly eight times their share of the total population, is also imposing some significant stigma costs. But to some there may be important symbolic differences between treating people as criminals after they have committed a crime and treating them as potential criminals before they have actually done anything. 
though young men commit the vast majority of violent crimes, the best way to reduce their criminality could nevertheless be by reaching their wives/ girlfriends/mothers.

For these reasons, we do not take our analysis as a call for targeting benefits on race or gender grounds but, rather, merely as a demonstration of the conditions under which spending on certain enriched social programs can generate substantial crime-reduction benefits at no greater social cost than the incarceration policy it would supplant. If we know that crude race and gender targeting could meet our crime-reduction goals, then a more sophisticated targeting system (assuming the constitutional impediments can be overcome) would provide even greater benefits at lower costs. Many of the concerns about actual program implementation have not been problematic for programs such as the Job Corps, which predominantly serves innercity black males, but without explicitly targeting any demographic group. Once a sophisticated targeting strategy is developed, it may be possible to design the program in a way that the parents or guardians of those most at risk for future criminality will disproportionately seek to participate. Since the successful programs we describe were not specifically designed as anticrime measures, it should presumably be possible to avoid attaching this label to them, which would help to avoid some of the stigma problems discussed earlier. ${ }^{95}$

\section{Public Choice Aspects of Crime Policy}

Finally, we must note that the strategy we have outlined might be politically difficult to implement. Doubtless, there are reasons why American society seems so committed to the incarcerative approach. Our proposal to shift resources away from further prison building to social spending would provide educational, emotional, and psychological gains and lower crime rates for program participants and their families and communities, who are likely to be members of politically disadvantaged groups. At the same time, even though the combination of more social spending and less incarceration would not increase crime overall, it might increase crime somewhat in the more politically influential and affluent communities. The reason is that the curtailed increase in the expected penalty for criminals would in itself tend to increase crime everywhere, but this increase would be offset by crimereducing social programs that would likely most benefit poor communities. Although the overall social costs and benefits of this policy might be

\footnotetext{
95 We might be able to finesse some of the selection problems by basing entry into the programs on race/gender-neutral characteristics such as income or distressed family characteristics (for example, single parenthood).
} 
appealing-that is, it might be both efficient and equality-enhancing-it might not be distributionally palatable since the high-payoff, targetedprevention strategy advantages groups who are numerical minorities with relatively low political power at the expense of those with greater numbers and more clout. Moreover, preschool programs impose costs today and yield benefits in 15-20 years, which is not an appealing formula for most politicians. Thus, shifting resources from incarceration to social programs may not be a politically sustainable policy.

\section{Conclusion: Some Cautions-Scale and Other Effects}

As noted earlier, most of the successful experimental interventions we discussed (with the exception of the Job Corps) were conducted on extremely limited scales, typically with fewer than 100 participants. Our thought experiment involves massive increases in these programs, rather than the marginal adjustments that make policy analysts feel most comfortable.

Expanding these social programs by many orders of magnitude will not be straightforward, for a number of reasons. Costs will presumably rise as we move up the supply curve for the kinds of high-quality teachers and other personnel needed to staff these programs. The team spirit and morale that seem to have been so important in the success of the small projects are likely to be eroded in the larger, more bureaucratic organizations that will be necessary to run nationwide programs. (Indeed, to some degree, this is the message of Head Start. Because the Perry Preschool looked promising, Congress massively increased spending on the far less expensive and less valuable Head Start program.) Differences between the original experimental samples and the broader populations to be served may reduce the effects of the treatments. Some of the experiments were conducted as long as 30 years ago; social conditions have undoubtedly changed during the past 3 decades, perhaps in a way that would make the programs less effective than they originally were, even for an otherwise similar population of children.

For all these reasons, therefore, the hypothetical calculations we have presented should not be read to suggest that immediate, large-scale implementation of any of the programs is desirable. Rather, our point is simply that there may be scope for welfare-increasing large-scale interventions and that society should begin the process of trying to see whether such interventions can actually be carried out on a meaningful scale, rather than unthinkingly committing itself to a policy of massive prison construction without a full awareness of all of its attendant financial and human costs. 